Article

\title{
Impact Assessment of Gridded Precipitation Products on Streamflow Simulations over a Poorly Gauged Basin in El Salvador
}

\author{
Patricia Jimeno-Sáez ${ }^{1, *(D)}$, Pablo Blanco-Gómez ${ }^{1} \mathbb{D}$, Julio Pérez-Sánchez ${ }^{1,2}{ }^{\mathbb{D}}$, José M. Cecilia ${ }^{3}$ \\ and Javier Senent-Aparicio ${ }^{1}$ iD
}

1 Department of Civil Engineering, Universidad Católica San Antonio de Murcia, Campus de Los Jerónimos s/n, 30107 Murcia, Spain; pblanco4@alu.ucam.edu (P.B.-G.); jperez058@ucam.edu or julio.sanchez@ulpgc.es (J.P.-S.); jsenent@ucam.edu (J.S.-A.)

2 Department of Civil Engineering, Universidad de Las Palmas de Gran Canaria, Campus de Tafira, 35017 Las Palmas de Gran Canaria, Spain

3 Department of Computer Engineering (DISCA), Universitat Politécnica de Valencia (UPV), 46022 Valencia, Spain; jmcecilia@disca.upv.es

* Correspondence: pjimeno@ucam.edu

Citation: Jimeno-Sáez, P.; Blanco-Gómez, P.; Pérez-Sánchez, J.; Cecilia, J.M.; Senent-Aparicio, J. Impact Assessment of Gridded Precipitation Products on Streamflow Simulations over a Poorly Gauged Basin in El Salvador. Water 2021, 13, 2497. https://doi.org/10.3390/ w13182497

Academic Editor: Momcilo Markus

Received: 16 July 2021

Accepted: 8 September 2021

Published: 11 September 2021

Publisher's Note: MDPI stays neutral with regard to jurisdictional claims in published maps and institutional affiliations.

Copyright: (c) 2021 by the authors. Licensee MDPI, Basel, Switzerland. This article is an open access article distributed under the terms and conditions of the Creative Commons Attribution (CC BY) license (https:/ / creativecommons.org/licenses/by/ $4.0 /)$.
Abstract: In this study, five open access gridded precipitation (GP) products (CFSR, MSWEPv1.1, PERSIANN-CDR, CMORPH, and CHIRPSv2.0) and local climate data were evaluated over the Grande de San Miguel (GSM) River Basin in El Salvador. The main purpose was to identify optional data sources of precipitation for hydrological modelling given that ground-based precipitation gauges in El Salvador are scarce and their data includes important temporal and spatial gaps. Firstly, a direct comparison was made between the precipitation data from the five GP products and from the rain gauges. Secondly, the SWAT model was used to simulate the streamflow regimen based on the precipitation datasets. The analysis of results showed that the models produced correct predictions, and the accuracy increased as models were calibrated to each specific precipitation product. Overall, PERSIANN-CDR produced the best simulation results, including streamflow predictions in the GSM basin, and outperformed other GP products and also the results obtained from data precipitation gauges. The findings of this research support the hydrological modelling based on open-access GP products, particularly when the data from precipitation gauges are scarce and poor.

Keywords: gridded precipitation products; data-scarce regions; hydrological modelling; SWAT; streamflow; El Salvador

\section{Introduction}

Precipitation is a vital input in the numerical simulation of the hydrological responses in a river basin. A precise reproduction of the spatiotemporal variability of precipitation is crucial to accurately simulate hydrological processes. However, the limited availability of observed hydro-meteorological data often hinders streamflow modelling efforts, particularly in developing countries and in remote areas where measured data are unavailable or non-existent. Even when measured data exist, their quality can be very poor and free access to them may be limited due to a strict data transfer policy [1].

The traditional method of obtaining spatial precipitation data is through ground observations from a network of rain gauges. However, in poorly monitored areas, data interpolation is necessary and may produce uncertainty [2] and even significant mismatches between actual and estimated precipitation [3]. Furthermore, rain gauges are not always accurate devices for measuring real precipitation. Specifically, disparities between the measurements and real values of precipitation may be caused by the effects of wind above the gauge orifice, flaws in the rain gauge installation, losses by wetting and evaporation on the inside walls of the rain gauge, and other random and systematic errors [4,5]. Therefore, 
there is an evident need to enhance data collection and/or explore more accurate alternatives to ground-based data from rain gauges. One useful alternative source of data for poorly gauged and/or ungauged basins is the global gridded precipitation (GP) products that provide continuous precipitation with extensive spatial coverage and much finer spatial resolutions than terrestrial rain gauges [6].

Several GP data are operationally available and provide precipitation maps with different ranges of spatial resolutions (from $0.05^{\circ} \times 0.05^{\circ}$ to $1^{\circ} \times 1^{\circ}$ ) and time scales (hourly, daily, and monthly). The following are some of the most widely used products based on satellite data in the hydrology field: Multi-Source Weighted-Ensemble Precipitation (MSWEP) [7], Precipitation Estimate from Remotely Sensed Information using Artificial Neural Networks-Climate Data Records (PERSIANN-CDR) [8], National Oceanic and Atmospheric Administration Climate Prediction Center morphing technique product (CMORPH) [9] and the Climate Hazards group Infrared Precipitation with Stations dataset (CHIRPS) [10]. Other gridded meteorological products that have been widely used in hydrological modelling include global reanalysis data, such as the Climate Prediction System Reanalysis (CFSR) [11].

The values of the precipitation grids may be subjected to various sources of error including atmospheric effects that change the radiation field, limited correlation between remote sensing signals and precipitation rates or gaps [12]. Therefore, exhaustive validation is required, and in this sense numerous studies of precipitation grids have been conducted to improve its use. Furthermore, efforts to deepen the knowledge on their uncertainties have been carried out over different regions, increasing the accuracy of hydrological modelling using these precipitation data products. The validation of GP products can be conducted in two ways: by directly comparing the data with gauge rainfall [3,13-17] and by analyzing their ability to reproduce observed streamflow using hydrologic models $[3,15,17]$.

The Soil and Water Assessment Tool (SWAT) model [18] is one of the most popular models used at the basin scale. SWAT has been widely applied in numerous studies around the world to resolve several processes, such as water balance, climate and land-use changes, agricultural pollution from nonpoint sources, and land management [19-24]. Recent SWAT studies $[1,17,25,26]$ showed a growing trend towards the use of alternatives to rain gauge networks. The calibration of hydrological models is subject to the type of precipitation data source. In previous research conducted in a different area of El Salvador [27], good statistics were obtained in the SWAT hydrological model using CHIRPS as input. Many previous studies $[28,29]$ calibrated SWAT parameters with the monitored rainfall, and they subsequently executed simulations with GP using these parameter values without any additional calibration. However, if the observed data are not reliable, then the calibrated model will be inaccurate. Other studies [25,30-32] considered the impact on the calibration of each data source and the sensitivity of the associated parameters by calibrating the SWAT model with each different precipitation source. However, the parameters forced on each set of data may hide data errors. Notwithstanding, very few studies have used both methodologies to validate the different precipitation products [33,34].

Despite the numerous studies around the world, knowledge about the abilities and limitations of GP products in Latin America, a region where the scarcity of weather stations is the norm, remains scarce and limited. Dinku et al. [14] found that the GP products were poor at estimating the amount of daily precipitation but good at detecting the occurrence of precipitation events over Colombia, with relatively good performance for CMORPH and a low performance using PERSIANN and TRMM 3B42RT. Blacutt et al. [35] assessed two reanalysis datasets (Modern-Era Retrospective Analysis for Research and Applications (MERRA) [36] and CFSR), a satellite product (TRMM3B42) [37], and a combined product (CoSch), which successfully eliminates satellite bias, in four areas of Bolivia.. Melo et al. [38] found a low performance of TRMM 3B42v6 and 3B42v7 in daily and seasonal analysis over Brazil. Zambrano-Bigiarini et al. [39] evaluated seven satellite products for the Chilean territory and found that CHIRPSv2.0, TRMM 3B42v7, and MSWEPv1.1 provided relatively good results. Baez-Villanueva et al. [13] evaluated six satellite-based rainfall 
datasets (TRMM 3B42v7, TRMM 3B42RT, CHIRPSv2.0, CMORPH, PERSIANN-CDR, and MSWEPv2) over three different basins in Latin America (Colombia, Chile, and Brazil), and they showed that for the basin in Brazil, MSWEPv2 offered the best performance, while CHIRPSv2.0 performed the best for the basin in Colombia, and MSWEPv2 and CHIRPSv2.0 performed the best in Chile. Even fewer studies in Latin America evaluate the ability of different GP products to reproduce the observed streamflow. Oliveira et al. [40] used rainfall data from TRMM3B42V6 and V7 to evaluate the water balance of a Brazilian region, and they found that the precipitation from 3B42V7 provided a lower overestimate of stream discharge compared to the 3B42V6 dataset. However, the use of alternative climate products for hydrological purposes is widespread worldwide [41], such as in data-scarce countries in Asia [17,42-44] or Africa [1,26,31,45,46].

This study provides an overview of the quality of different sources of precipitation for hydrological applications in a poorly gauged Central American basin. In addition to evaluating the replication of the streamflow regimen, a direct comparison was made between the precipitation data from the five GP products and the precipitation data from the rain gauges. This will also contribute to contrasting not only the disparities between ground-based data and GP products, but also the resulting water balances and the quality and accuracy of the precipitation data products studied. Specifically, the goals of this study are (1) to assess the spatiotemporal performance of five high-resolution precipitation products and compare them with monitored precipitation data in a tropical climate basin in El Salvador at different time scales, and (2) to assess the ability of these precipitation datasets to simulate monthly observed streamflow in SWAT using two calibration strategies: (a) calibrating with data from the observed precipitation and then running the simulations using the GP, and (b) calibrating the SWAT parameters with each of the precipitation sources.

\section{Materials and Methods}

The methodology used for this comparative study of the different sources of precipitation is shown below and summarized in Figure 1, as described previously.

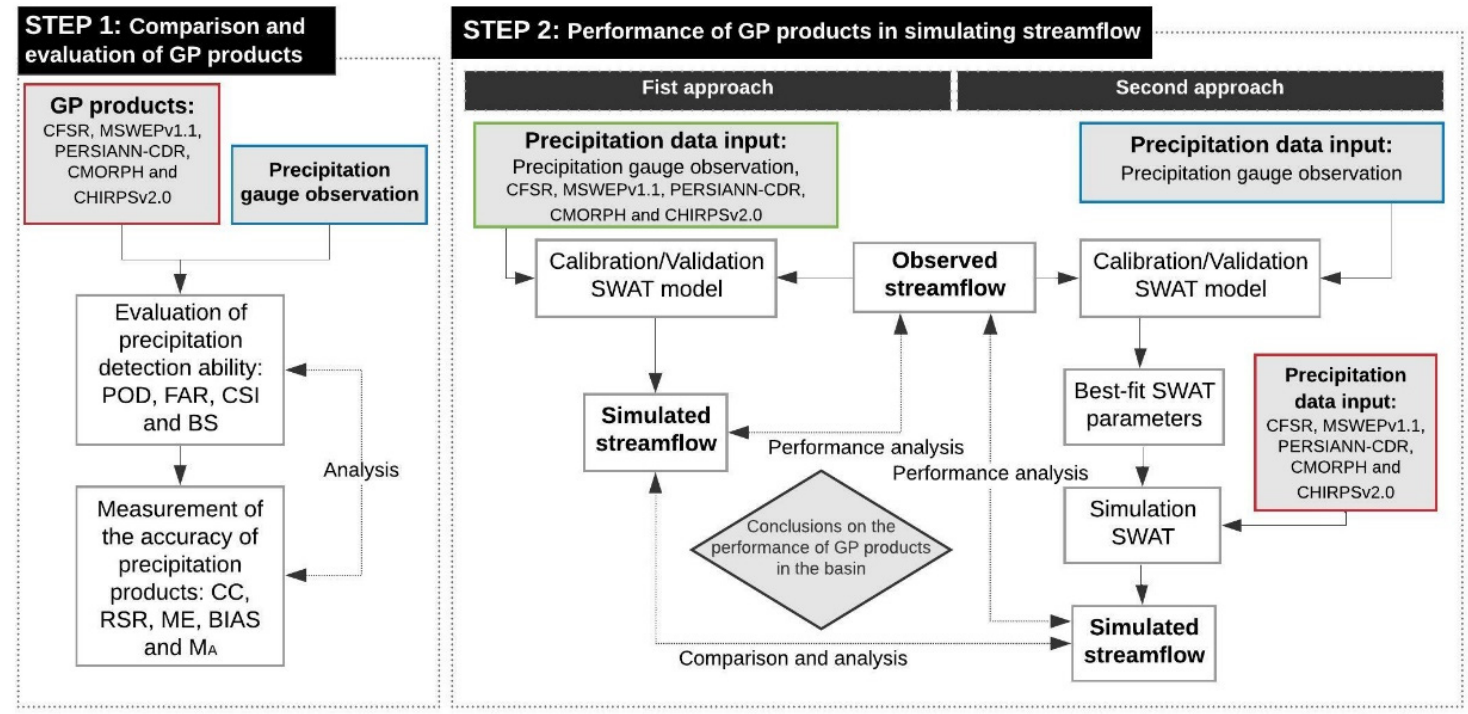

Figure 1. Flowchart for comparative study.

\subsection{Study Area}

The GSM River Basin is located in eastern El Salvador and covers an area of $2377 \mathrm{~km}^{2}$ up to the outlet control point (Figure 2). This basin is one of the most important and largest river basins in El Salvador. The city of San Miguel is located at its centre and is considered demographically to be the second most important city in El Salvador. The GSM River Basin is regarded as a priority area (PA) within the National Plan of Integrated Water Resources 
Management of El Salvador [47]. Each PA is the object of special measures regarding water resource management due to the hydrological problems identified. Specifically, the major problems in the GSM River Basin are the pollution of surface water and the high irrigation water demand, creating substantial stress on water resources [47]. An accurate understanding of the hydrological processes at the basin scale is necessary to propose efficient management strategies to minimize the effect of these stress factors. Furthermore, the city of San Miguel has attracted environmental interest in terms of international protection figures, such as the Tepaca-San Miguel and Jiquilisco Bay conservation areas. Tecapa-San Miguel is characterized by shade-grown coffee plantations, an abundance of coastal plain wetlands, and volcanic craters, including multiple protected areas such as the San Miguel Volcano and the El Jocotal and Olomega lagoons, both of which are part of the Ramsar List of the Convention of Wetlands. The Jiquilisco Bay located in the mouth of the Grande de San Miguel River has been recognized as a Ramsar site since 2005 and as a UNESCO biosphere reserve since 2007.
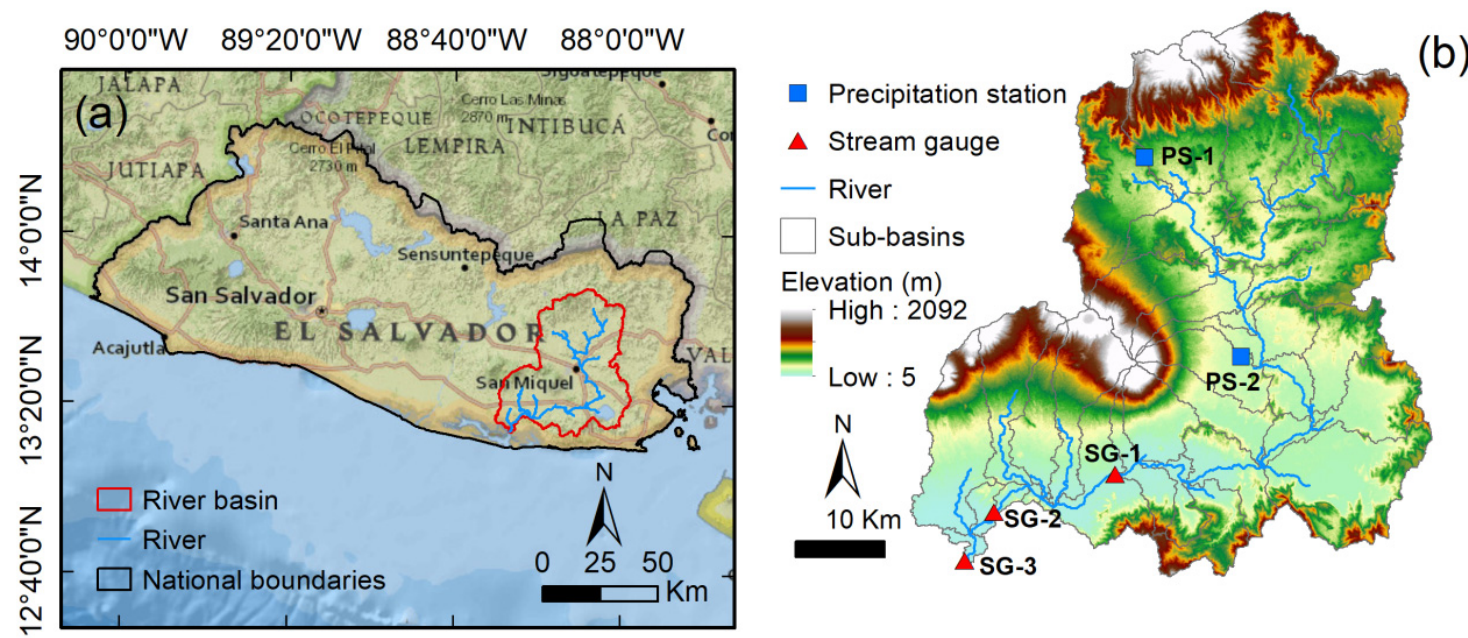

(b)

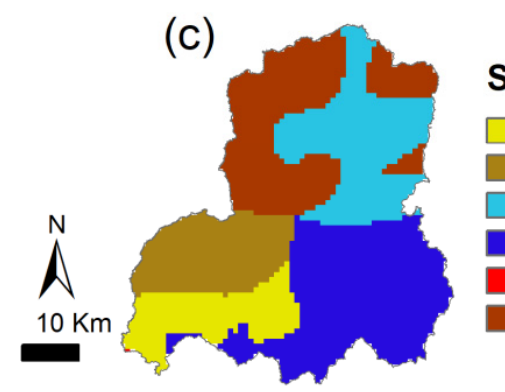

\section{Soil type}

Umbric Andosols-Haplic Andosols-Vitric Andosols-Mollic Andosols

Umbric Andosols-Haplic Andosols-Vitric Andosols

Luvic Phaeozems-Eutric Vertisols

Luvic Phaeozems-Eutric Regosols

Eutric Regosols-Eutric Gleysols

Eutric Regosols-Eutric Cambisols-Haplic Phaeozems

\section{Land use type}

\begin{tabular}{ll}
\hline Agricultural Land-Generic & $\square$ Mosaic cropland/grassland \\
Baren or sparsly vegetated & $\square$ Oil Palm \\
Citrus Fruit Plantations & Pasture \\
Coffee & Range-Brush \\
\hline Dryland Cropland and Pasture & Residential-High Density \\
\hline Forest-Deciduous & Residential-Med/Low Density \\
\hline Forest-Evergreen & Shrubland \\
\hline Forest-Mixed & Sugarcane \\
\hline Grassland & Transportation \\
\hline Herbaceous Wetland & Water Bodies \\
\hline Industrial & Wetlands-Forested \\
\hline Meadow Bromegrass &
\end{tabular}

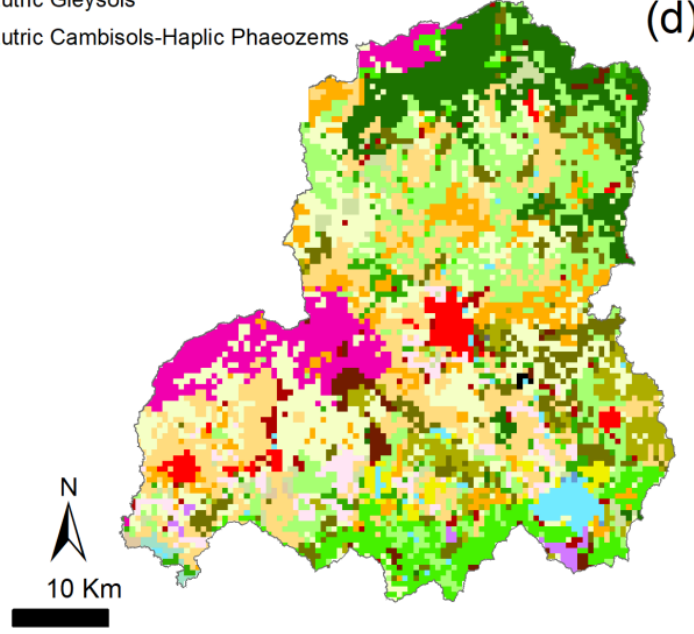

Figure 2. (a) Location of GSM River Basin in El Salvador; (b) topography of the basin and location of hydro-meteorological stations; (c) soil map of the basin and (d) land use map of the basin. 
While the region has a tropical climate with high annual rates of precipitation, the intraannual distribution is uneven. Specifically, $90 \%$ of the precipitation falls during the wet season between May and October, and only scattered showers occur during the dry season between November and April $[27,48]$. According to observations of the weather stations and the GP analysed, the mean annual precipitation is around $1700-2000 \mathrm{~mm}$, which is consistent with previous studies [48]. The wettest months are August and September, with average monthly rainfall values of 290 and $298 \mathrm{~mm}$. January and February have the lowest rainfall, with an average monthly rainfall of $2 \mathrm{~mm}$. The average annual temperature in the basin is $28^{\circ} \mathrm{C}$, with maximum and minimum values of 33 and $22{ }^{\circ} \mathrm{C}$, respectively. The dominant soil groups in the region are classified as andosols, phaeozems, and regosols (Figure 2c). The andosols that cover the area associated with the San Miguel volcano are volcanic soils and have favourable properties for agriculture [49]. The dominant soil types at the northern boundaries are regosols, unconsolidated materials with fine granulometry common in mountainous areas, whilst throughout the eastern part of the basin, phaeozem soils are abundant and accommodate wet grasslands and forest regions as they are characteristically porous, fertile, and excellent agricultural land [50]. Regarding the basin hydrogeology, previous studies [51] indicate high permeability, fissure flows and a faster recharge response [52]. The main land-use types are grassland and pasture (43\%), cropland $(32 \%)$, and forest (17\%). The land use map of the basin shown in Figure $2 \mathrm{~d}$ is based on RapidEye imagery satellite at $5 \mathrm{~m}$ spatial resolution [53].

\subsection{Precipitation Datasets}

In this study, six datasets were selected. Table 1 summarizes the list of precipitation products used, their spatial and temporal resolution, their available period, and their spatial coverage. These precipitation datasets can be grouped into three categories: (1) one observed precipitation dataset from ground precipitation gauges located within the GSM River Basin; (2) one reanalysis gridded product (CFSR); and (3) four gridded satellite-based precipitation datasets (MSWEPv1.1, PERSIANN-CDR, CMORPH, and CHIRPSv2.0).

Table 1. List of precipitation datasets used.

\begin{tabular}{ccccc}
\hline Product & Spatial Resolution & Time-Step & $\begin{array}{c}\text { Available } \\
\text { Period }\end{array}$ & Spatial Coverage \\
\hline Gauge observation & Point & Daily & $2005-2010$ & Study area \\
CFSR & $0.30^{\circ} \times 0.30^{\circ}(\sim 38 \mathrm{~km})$ & Daily & $1979-2014$ & Global \\
MSWEPv1.1 & $0.25^{\circ} \times 0.25^{\circ}(\sim 30 \mathrm{~km})$ & Daily & $1979-2015$ & Global \\
PERSIANN-CDR & $0.25^{\circ} \times 0.25^{\circ}(\sim 30 \mathrm{~km})$ & Daily & 1983 -present & Latitude band $60^{\circ} \mathrm{N}-\mathrm{S}$ \\
CMORPH & $0.25^{\circ} \times 0.25^{\circ}(\sim 30 \mathrm{~km})$ & Daily & 1998 -present & Latitude band $60^{\circ} \mathrm{N}-\mathrm{S}$ \\
CHIRPSv2.0 & $0.05^{\circ} \times 0.05^{\circ}(\sim 5.3 \mathrm{~km})$ & Daily & 1981 -present & Latitude band $50^{\circ} \mathrm{N}-\mathrm{S}$ \\
\hline
\end{tabular}

After intensive analyses of measured precipitation data, two stations within the basin (PS-1 and PS-2 in Figure 2b) were selected from six existing stations in the area for the study period (2005-2010). Four stations were excluded following the Tan and Yang [54] criterion for tropical basins, which states that rainfall gauges with more than $20 \%$ missing data would significantly affect streamflow simulation. The missing values in PS-1 and PS-2 were $16 \%$ and $8 \%$, respectively. The hydrological model filled the missing weather data automatically using SWAT's built-in weather generator. The gaps and scarcity of data in this country, as mentioned in a previous study [27], was the main driver for this research to explore the potential of open access alternative precipitation data. Details on the GP products are available in the Supplementary Material.

\subsection{Precipitation Comparison}

Daily precipitation information was extracted from the grid cells that contained the gauge observation stations, and the days without observed data were excluded from the gridded data in the comparative study. We evaluated the closest grid cell of each GP 
product to the respective rain gauge. It is to be noted that this is a limitation of the study, as the different resolution of the GP products penalises the coarser datasets and may bias the assessment. The period from 2005 to 2010 was selected to assess the accuracy of the precipitation datasets.

The ability to detect the occurrence of rainfall events of each precipitation product was assessed by using four categorical indexes: (1) the probability of detection (POD); (2) false alarm ratio (FAR); (3) critical success index (CSI); and (4) bias score (BS). The POD provides the capability of precipitation products to accurately capture the actual precipitation occurrence. FAR assesses the fraction of false alarms detected by the products of precipitation. The ability of the data to comprehensively detect true precipitation events is measured by CSI. CSI is an accurate and balanced detection metric and is based on POD and FAR. BS is the ratio of the estimated to observed rain. Five quantitative performance metrics were employed to measure the accuracy of the precipitation datasets in terms of the amount of rain and time dynamics (three time scales: day, month, and year): (1) correlation coefficient (CC); (2) RMSE-observations standard deviation ratio (RSR); (3) mean error (ME); (4) relative bias (BIAS); and (5) annual mean precipitation $\left(\mathrm{M}_{\mathrm{A}}\right)$. The $\mathrm{CC}$ explains the degree of linear correlation between gauge observations and GP products. RSR incorporates the benefits of error index statistics and includes a normalization factor. ME provides an assessment of the bias in the estimates, while BIAS indicates the degree to which the observed value is overestimated or underestimated as a percentage. The formulae and optimal values for each precipitation performance metric are presented in Table 2.

Table 2. Precipitation performance metrics.

\begin{tabular}{|c|c|c|c|}
\hline Statistic & Equation $^{1}$ & Unit & Optimal Value \\
\hline POD & $\frac{N_{11}}{N_{11}+N_{10}}$ & - & 1 \\
\hline FAR & $\frac{N_{10}}{N_{11}+N_{10}}$ & - & 0 \\
\hline CSI & $\frac{N_{11}}{N_{11}+N_{01}+N_{10}}$ & - & 1 \\
\hline BS & $\frac{N_{11}+N_{10}}{N_{11}+N_{01}}$ & - & 1 \\
\hline $\mathrm{CC}$ & $\frac{\sum_{i=1}^{n}\left(O_{i}-\bar{O}\right)\left(G_{i}-\bar{G}\right)}{\sqrt{\sum_{i=1}^{n}\left(O_{i}-\bar{O}\right)^{2}} \cdot \sqrt{\sum_{i=1}^{n}\left(G_{i}-\bar{G}\right)^{2}}}$ & - & 1 \\
\hline RSR & $\frac{\sqrt{\sum_{i=1}^{n}\left(O_{i}-G_{i}\right)^{2}}}{\sqrt{\sum_{i=1}^{n}\left(O_{i}-\bar{O}\right)^{2}}}$ & - & 0 \\
\hline ME & $\frac{\sum_{i=1}^{n}\left(G_{i}-O_{i}\right)}{n}$ & $\mathrm{~mm}$ & 0 \\
\hline BIAS & $\frac{\sum_{i=1}^{n}\left(G_{i}-O_{i}\right)}{\sum_{I=1}^{n} O_{i}} \cdot 100$ & $\%$ & 0 \\
\hline
\end{tabular}

${ }^{1}$ Note: $N_{11}$ represents the observed precipitation that was correctly detected; $N_{01}$ is the observed precipitation not detected; $N_{10}$ is the precipitation detected but not observed; $O_{i}$ and $G_{i}$ are observed and GP; $i$ is the index of data and $n$ is the total number of measurements; $\bar{O}$ and $\bar{G}$ is the mean value of observed and GP.

Additionally, the cumulative density function (CDF) of the daily precipitation distribution was computed for the six datasets. The cumulative frequency was evaluated based on the precipitation event classification of the World Meteorological Organization (WMO) standard [55] as presented in Table 3.

Table 3. Precipitation event classification based on daily rainfall intensity.

\begin{tabular}{cc}
\hline Type of Event & Daily Rainfall Intensity (mm/Day) \\
\hline Tiny rain & $<1$ \\
Light rain & {$[1,2)$} \\
Low modeerate rain & {$[2,5)$} \\
High moderate rain & {$[5,10)$} \\
Heavy rain & {$[10,50)$} \\
Violent rain & $\geq 50$ \\
\hline
\end{tabular}




\subsection{Precipitation Performance in Simulating Streamflow}

Since the results presented in the previous section were sensitive to the quality of the observed data (which was questionable and of poor quality in this study area), a second analysis was performed based on the simulation of streamflow.

In this study, the SWAT hydrological model was used to assess the reliability of precipitation products in predicting the observed streamflow. The model assessed how the different precipitation sources might affect the model calibrations and its performance and the hydrological coherence of precipitation datasets with hydrological observations.

\subsubsection{SWAT Hydrological Model}

SWAT is a physically based hydrological model that operates on a watershed scale in a semi-distributed way and simulates the main components of the water balance continuously on a daily scale [18]. SWAT divides river basins into sub-basins according to topography and the network of rivers; subsequently, sub-basins are subdivided into hydrologic response units (HRUs). HRUs group land areas with unique combinations of land use, soil, and slope, describing the spatial heterogeneity within a watershed [56]. SWAT simulates the hydrological cycle by calculating the runoff of each HRU individually and then aggregating it to the sub-basin level based on the water balance.

\subsubsection{Model Set-Up and Sensitivity Analysis}

The open-source QSWAT version 2012 [56], a QGIS interface for SWAT, was employed to construct a model of the GSM River Basin. Multiple datasets were needed to model, calibrate and validate the SWAT model, including daily climatic data (precipitation, maximum and minimum air temperature), geographic information (digital elevation model (DEM), soil properties, and land use/land cover data (LULC)), and hydrological datasets. The six selected sources of precipitation are described in the previous section. The SWAT model distributes the meteorological data to the sub-basins using the data from a single station or cell data that are closest to the centroid of each sub-basin [57]. Figure 3 presents the spatial resolution of the GP products with the centroids of the sub-basins of the SWAT model. Due to the scarcity of measured data in this region, daily temperature records were derived from the CFSR dataset. The topography of the basin was defined from the DEM to delineate the basin boundary, determine the stream network, and establish sub-basins. The DEM (Figure 2b) used in this study had a resolution of $30 \mathrm{~m}$ and was downloaded from the Advanced Spaceborne Thermal Emission and Reflection Radiometer Global Digital Elevation Model version 2 (ASTER GDEM v2) by NASA (https:/ / asterweb.jpl.nasa.gov/gdem.asp (accessed on 5 May 2021)). The soil and LULC data were important to define the HRUs. Soil data (Figure 2c) were taken from the Harmonized World Soil Database (HWSD) and can be downloaded from http:/ / www.fao.org/land-water/databases-and-software/hwsd/en/ (accessed on 5 May 2021). The LULC map (Figure 2d) and observed discharges were acquired from the Ministry for the Environment and Natural Resources of El Salvador (MARN). Using these data, the GSM River Basin was divided into 41 sub-basins (Figure 2b) and 579 HRU. The data of the monthly observed discharges are available from 1970 to 2012 in three hydrological stations (SG-1, SG-2, and SG-3), the locations of which are shown in Figure $2 \mathrm{~b}$. The Hargreaves method [58] was used to calculate the potential evapotranspiration using maximum and minimum daily air temperatures as input data. The curve number (CN) method of the Soil Conservation Service (SCS) [59] was used to compute the surface runoff and infiltration for each HRU using daily precipitation. After rigorous analysis of the observed data, the period 2005 to 2010 was selected, for which all the necessary data for SWAT calibration and validation were available. A two-year period was used to warm up the model. 

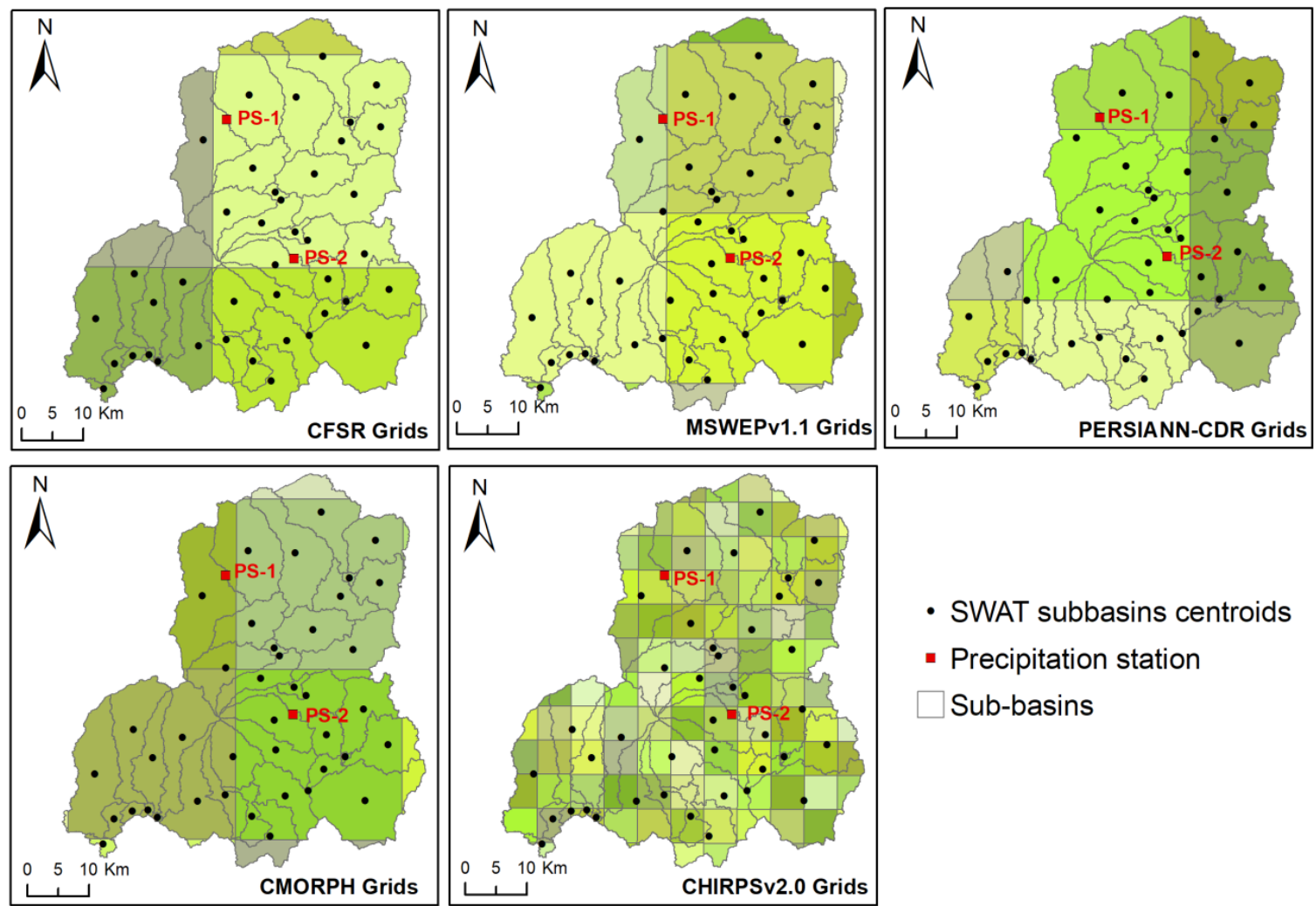

- SWAT subbasins centroids

- Precipitation station

Sub-basins

Figure 3. Precipitation grids with the sub-basin centroids.

\subsubsection{Model Calibration and Validation}

The performance of SWAT models was assessed for each GP product with two different strategies to consider the effect of each data source on the process of calibration and sensitivity of the associated parameters. The first approach entailed the calibration of the SWAT model using gauge observations, and then the best-fitted parameters found were used with each GP product as input without additional calibration. The second approach was the calibration and validation of the SWAT model using each of the different precipitation sources (Figure 1).

The calibration of models was performed using the SUFI-2 algorithm [60] in the SWAT-CUP software [61]. The models were calibrated from 2005 to 2007 and validated for the 2008 to 2010 period. According to the recommendations of Arnold et al. [62], the period of calibration and validation contained both dry and wet periods to ensure that they reflected the range of conditions under which the model was expected to operate. Based on the authors' previous experience and the available literature [27,28], some sensitive hydrological parameters in the simulation of streamflow, and which incorporated aspects of soil, groundwater, and surface water, were selected. Firstly, 500 model runs with the gauge observation precipitation dataset were conducted and the least sensitive parameters were excluded. Thereafter, two iterations of 1000 simulations were executed with the 16 most sensitive parameters (Table 4), using the corresponding precipitation dataset as input, and adjusting the range of parameters in the second iteration. The same 16 parameters were used to calibrate all SWAT models, using the same initial range (Table 4) for each of them to allow a correct comparison and starting point.

The parameters were calibrated by comparing simulated streamflow with monitored streamflow in the three stream gauges (Figure 2b), and the Nash-Sutcliffe Efficiency (NSE) [63] was used as the objective function. Four model performance metrics defined in Table 5 were calculated to assess the performance of monthly streamflow simulation for each SWAT model following the criteria and performance ratings suggested by Moriasi et al. [64]. 
Table 4. SWAT calibration parameters.

\begin{tabular}{|c|c|c|c|}
\hline Type & Parameter $^{1}$ & Description & Initial Range \\
\hline Management & r_CN2 & SCS runoff curve number & {$[-0.2,0.2]$} \\
\hline Groundwater & v_ALPHA_BF & Baseflow alpha factor (days-1) & {$[0,1]$} \\
\hline Groundwater & v_GWQMN & $\begin{array}{c}\text { Threshold depth of water in the shallow aquifer for } \\
\text { return flow to occur (mm) }\end{array}$ & {$[0,5000]$} \\
\hline Groundwater & v_GW_REVAP & Groundwater "revap" coefficient & {$[0.02,0.20]$} \\
\hline Groundwater & v_RCHRG_DP & Deep aquifer percolation fraction & {$[0,1]$} \\
\hline Groundwater & v_SHALLST & Initial depth of water in the shallow aquifer (mm) & {$[0,1500]$} \\
\hline HRU & v_CANMX & Maximum canopy storage $(\mathrm{mm})$ & {$[0,50]$} \\
\hline HRU & r_SLSUBBSN & Average slope length & {$[-0.5,0.5]$} \\
\hline HRU & r_HRU_SLP & Average slope steepness & {$[-0.5,0.5]$} \\
\hline Basin & v_ESCŌO & Soil evaporation compensation factor & {$[0.1,1]$} \\
\hline Basin & v_SURLAG & Surface runoff lag time & {$[0.05,24]$} \\
\hline Routing & v_CH_N2 & Manning's " $\mathrm{n}$ " value for the main channel & {$[-0.01,0.3]$} \\
\hline Routing & v_CH_K2 & $\begin{array}{c}\text { Effective hydraulic conductivity in main } \\
\text { channel alluvium }\end{array}$ & {$[0.01,150]$} \\
\hline Soil & r_SOL_AWC & $\begin{array}{l}\text { Available water capacity of the soil layer (mm } \\
\qquad \mathrm{H}_{2} \mathrm{O} / \mathrm{mm} \text { soil) }\end{array}$ & {$[-0.3,0.3]$} \\
\hline Soil & r_SOL_BD & Moist bulk density & {$[-0.3,0.3]$} \\
\hline Soil & r_SOL_Z & Depth from soil surface to bottom of layer & {$[-0.3,0.3]$} \\
\hline
\end{tabular}

${ }^{1} \mathrm{r}_{-}$denotes the relative change (the current value must be multiplied by $1+$ the value obtained in calibration), and $v_{-}$indicates that the existing value is replaced by the value obtained in the calibration.

Table 5. Model performance metrics.

\begin{tabular}{ccc}
\hline Performance Metric & Equation ${ }^{1}$ & Range \\
\hline Coefficient of determination $\left(R^{2}\right)$ & {$\left[\frac{\sum_{i=1}^{n}\left(O_{i}-\bar{O}\right) \cdot\left(S_{i}-\bar{S}\right)}{\left[\sum_{i=1}^{n}\left(O_{i}-\bar{O}\right)^{2}\right]^{0.5} \cdot\left[\sum_{i=1}^{n}\left(S_{i}-\bar{S}\right)^{2}\right]^{0.5}}\right]^{2}$} & {$[0,1]$} \\
Nash-Sutcliffe Efficiency (NSE) & $1-\frac{\sum_{i=1}^{n}\left(O_{i}-S_{i}\right)^{2}}{\sum_{i=1}^{n}\left(O_{i}-\bar{O}\right)^{2}}$ & {$[-\infty, 1]$} \\
Percent bias (PBIAS) & $\frac{\sum_{i=1}^{n}\left(O_{i}-S_{i}\right) \cdot 100}{\sum_{i=1}^{n}\left(O_{i}\right)}$ & {$[-\infty, \infty]$} \\
RMSE-observations standard deviation ratio (RSR) & $\frac{\sqrt{\sum_{i=1}^{n}\left(O_{i}-S_{i}\right)^{2}}}{\sqrt{\sum_{i=1}^{n}\left(O_{i}-\bar{O}\right)^{2}}}$ \\
\hline
\end{tabular}

${ }^{1} O_{i}$ is the ith observed streamflow value, $\bar{O}$ is the mean of the observed data, $S_{i}$ is the $i$ th simulated streamflow value, $\bar{O}$ is the mean of the observed data and $\mathrm{n}$ is the total number of observations.

\section{Results and Discussion}

\subsection{Comparison and Evaluation of GP Products}

Regarding precipitation detection ability assessment, Table 6 provides precipitation detection metrics (POD, FAR, CSI, and BS) for each GP product computed using a $1 \mathrm{~mm} /$ day threshold.

Table 6. Precipitation detection metrics based on comparison with gauge observation at PS-1 station and at PS-2 station.

\begin{tabular}{ccccccccc}
\hline \multirow{2}{*}{ Precipitation Dataset } & \multicolumn{4}{c}{ PS-1 Station } & \multicolumn{3}{c}{ PS-2 Station } \\
\cline { 2 - 9 } & POD & FAR & CSI & BS & POD & FAR & CSI & BS \\
\hline CFSR & 0.78 & 0.40 & 0.51 & 1.31 & 0.79 & 0.48 & 0.46 & 1.53 \\
MSWEPv1.1 & 0.93 & 0.41 & 0.57 & 1.57 & 0.91 & 0.46 & 0.51 & 1.69 \\
PERSIANN-CDR & 0.93 & 0.41 & 0.57 & 1.58 & 0.92 & 0.47 & 0.51 & 1.74 \\
CMORPH & 0.80 & 0.31 & 0.59 & 1.16 & 0.79 & 0.30 & 0.59 & 1.13 \\
CHIRPSv2.0 & 0.81 & 0.27 & 0.62 & 1.11 & 0.79 & 0.35 & 0.55 & 1.22 \\
\hline
\end{tabular}

POD values for all GP products were higher than 0.78. MSWEPv1.1 and PERSIANNCDR demonstrated the highest POD values due to their high number of rainy days against the monitored data (Table 6). In the case of FAR, the values range from 0.27 to 0.48 . 
CHIRPSv2.0 and CMORPH precipitation data provided lower values of FAR. CSI values showed a range of 0.51 to 0.62 for the PS- 1 station and 0.46 to 0.59 for the PS-2 station. As shown in Table 7, these low CSI values were obtained due to the high number of rainy days detected by all GP products compared to the observed data.

Table 7. Total number of days in which precipitation exceeds 1 (PD1) or 10 (PD10) $\mathrm{mm}$ in the period of study (2005-2010).

\begin{tabular}{ccccc}
\hline \multirow{2}{*}{ Precipitation Dataset } & \multicolumn{2}{c}{ PS-1 Station } & \multicolumn{2}{c}{ PS-2 Station } \\
\cline { 2 - 5 } & PD1 & PD10 & PD1 & PD10 \\
\hline Gauge observations & 600 & 339 & 558 & 282 \\
CFSR & 788 & 236 & 854 & 248 \\
MSWEPv1.1 & 942 & 369 & 944 & 339 \\
PERSIANN-CDR & 946 & 409 & 973 & 424 \\
CMORPH & 696 & 315 & 628 & 289 \\
CHIRPSv2.0 & 666 & 439 & 678 & 409 \\
\hline
\end{tabular}

The BS result, ranging from 1.11 to 1.74 , suggests that all GP products overestimate the total number of observed precipitation events. CHIRPSv2.0 and CMORPH showed the best BS values for both stations. When the threshold was adjusted to $10 \mathrm{~mm}$, the detection ability of all GP products for these heavy precipitation events demonstrated better agreement with the observed data. In conclusion, no GP datasets are highlighted for their ability to detect precipitation events in the studied basin.

Table 8 summarizes statistical indices for daily and monthly precipitation products against gauge observation in both stations and the $\mathrm{M}_{\mathrm{A}}$ value for each precipitation dataset.

Table 8. Daily and monthly statistical indices of precipitation products against gauge observation at stations PS-1 and PS-2.

\begin{tabular}{|c|c|c|c|c|c|c|c|c|c|}
\hline \multirow{2}{*}{$\begin{array}{c}\text { Station/Precipitation } \\
\text { Dataset }\end{array}$} & \multicolumn{2}{|c|}{$\mathrm{CC}$} & \multicolumn{2}{|c|}{ RSR } & \multicolumn{2}{|c|}{ ME } & \multicolumn{2}{|c|}{ BIAS $^{1}$} & \multirow{2}{*}{$\mathbf{M}_{\mathrm{A}}(\mathrm{mm})$} \\
\hline & Daily & Monthly & Daily & Monthly & Daily & Monthly & Daily & Monthly & \\
\hline \multicolumn{10}{|c|}{ PS-1 } \\
\hline Gauge observations & - & - & - & - & - & - & - & - & 1833.55 \\
\hline CFSR & 0.32 & 0.84 & 1.05 & 0.60 & -1.15 & -34.64 & -19.83 & -19.83 & 1526.50 \\
\hline MSWEPv1.1 & 0.51 & 0.82 & 0.88 & 0.59 & 0.11 & 3.39 & 1.94 & 1.94 & 1867.66 \\
\hline PERSIANN-CDR & 0.48 & 0.83 & 0.89 & 0.56 & -0.03 & -1.09 & -0.58 & -0.63 & 1813.24 \\
\hline CMORPH & 0.50 & 0.87 & 0.96 & 0.50 & -0.03 & -0.96 & -0.55 & -0.55 & 1805.05 \\
\hline CHIRPSv2.0 & 0.55 & 0.89 & 0.88 & 0.50 & 0.50 & 15.05 & 8.62 & 8.62 & 2058.75 \\
\hline \multicolumn{10}{|c|}{ PS-2 } \\
\hline Gauge observations & - & & - & - & - & - & - & - & 1553.04 \\
\hline CFSR & 0.27 & 0.86 & 1.10 & 0.52 & -0.25 & -5.38 & -5.49 & -5.38 & 1537.81 \\
\hline MSWEPv1.1 & 0.52 & 0.88 & 0.90 & 0.57 & 0.55 & 12.26 & 12.13 & 12.26 & 1752.64 \\
\hline PERSIANN-CDR & 0.47 & 0.90 & 0.91 & 0.53 & 0.82 & 17.98 & 17.88 & 17.98 & 1827.73 \\
\hline CMORPH & 0.47 & 0.84 & 1.03 & 0.60 & 0.02 & 0.85 & 0.73 & 0.85 & 1588.88 \\
\hline CHIRPSv2.0 & 0.53 & 0.94 & 0.91 & 0.45 & 0.61 & 13.48 & 13.34 & 13.48 & 1847.27 \\
\hline
\end{tabular}

${ }^{1}$ Note: Differences between daily and monthly BIAS are due to gaps in gauge observation datasets. Only months with all daily data available were compared.

Both stations showed daily CC values of approximately 0.5 and demonstrated that $\mathrm{CC}$ values of all precipitation datasets improved significantly on a monthly scale. High monthly correlations to observation were obtained, with values in the range of 0.82 to 0.94 . The best daily and monthly CC values were found for CHIRPSv2.0 precipitation at both stations. A noticeable difference between the daily and monthly scales was observed for RSR. The monthly RSR values of CHIRPSv2.0 were smaller than for the other GP products in both stations. For the PS-1 station, the best ME and BIAS values were demonstrated by CMORPH (daily ME of $-0.03 \mathrm{~mm}$, monthly ME of $-0.96 \mathrm{~mm}$, and BIAS of $-0.55 \%$ ), followed by PERSIANN-CDR with similar values (daily ME of $-0.03 \mathrm{~mm}$, monthly ME of $-1.09 \mathrm{~mm}$, daily BIAS of $-0.58 \%$ and monthly BIAS of $-0.63 \%$ ). For the PS- 2 station, 
the CMORPH again demonstrated the best values (daily ME of $0.02 \mathrm{~mm}$, monthly ME of $0.85 \mathrm{~mm}$, daily BIAS of $0.73 \%$, and monthly BIAS of $0.85 \%$ ). The ME and BIAS values for CFSR and PERSIANN-CDR showed the greatest discrepancies with the observations of the PS-1 station and PS-2 station, respectively. Regarding $\mathrm{M}_{\mathrm{A}}$ values, the greatest differences compared to the observed data were obtained by CFSR $(-307 \mathrm{~mm})$, followed by CHIRPSv2.0 (+225 mm) for the PS-1 station and by CHIRPSv2.0 (+294 mm) and PERSIANNCDR (+275 mm) for the PS-2 station. Monthly precipitations were computed from GP datasets and gauge observations to assess inter-annual variability. Figure 4 presents the box plot comparison of monthly precipitation from gauge observations, CFSR, MSWEPv1.1, PERSIANN-CDR, CMORPH, and CHIRPSv2.0 for the selected precipitation stations.

(a) PS-1

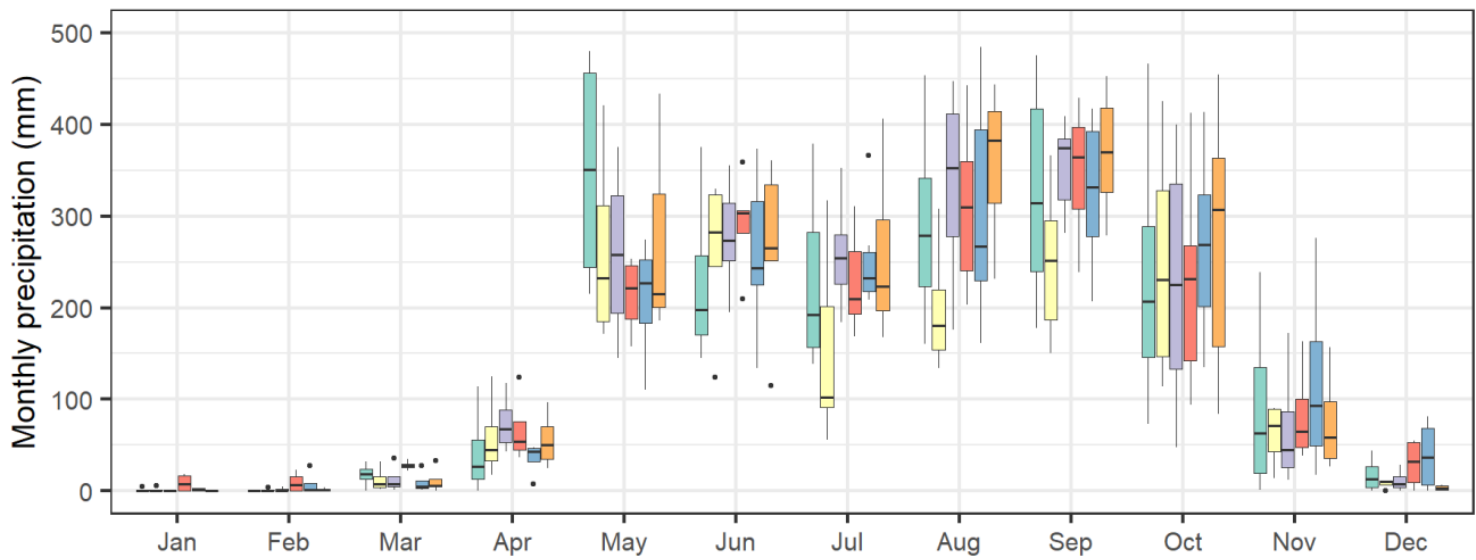

(b) PS-2

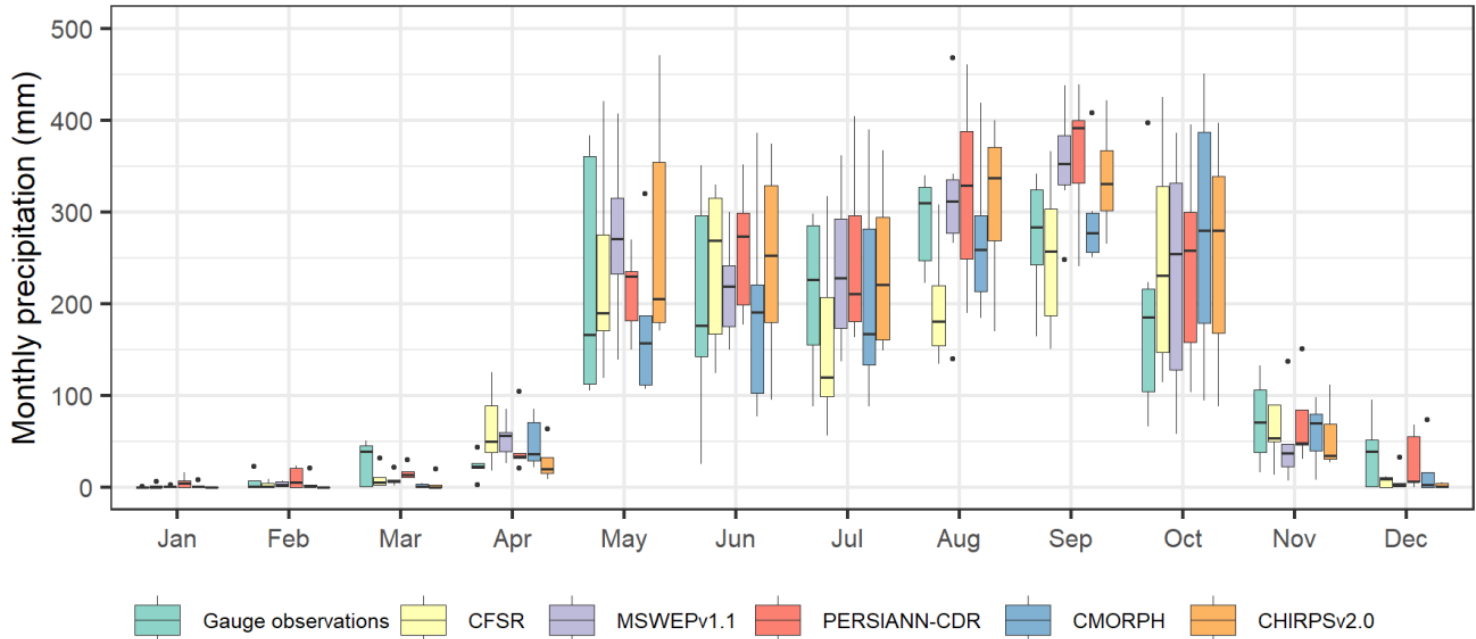

Figure 4. Box plot with the temporal distribution of the monthly precipitation of the gauge observations and of different GP products in (a) PS-1 station and (b) PS-2 station. Dots denote outliers.

GP products were similar to the gauge observations in both stations, reflecting the inter-annual variation of precipitation with a clearly distinguishable wet period from May to October and a dry period from November to April. Figure $4 \mathrm{a}, \mathrm{b}$ also show the bimodal distribution of the rainy summer season for most of the precipitation data, with maximum mean values in June and September and a relative minimum in July known as "Mid-Summer Drought" (MSD) [65], which is recognised as one of the most significant modulators of regional climate variability [27]. GP products, except for CFSR, generally overestimate the mean monthly precipitation observed in the wet season. 
Figures 5 and 6 show the CDF of daily precipitation in PS1 and PS2, respectively, for the observed values versus the six GP studied. Regarding the probability of dry days (rain $=0 \mathrm{~mm}$ ), both gauge stations and CHIRPSv2.0 provided a similar probability, of approximately $65 \%$. However, the other five GPs displayed lower probabilities that ranged from 32 to $36 \%$ (PS1-PS2, respectively) in the cases of CFSR and MSWEPv1.1 to 48 to $56 \%$ (PS1-PS2) for CMORPH, which is an increase in the number of rainy events compared to PS data. In fact, the CDFs in both stations were greater than the GP curves for precipitations below 10-20 $\mathrm{mm}$ due to the high percentage of days with no rain in PS1 and PS2. While minimal rain (lower than $1 \mathrm{~mm}$ ) did not reach 1\% in PS1, MSWEPv1.1 and CMORPH exceeded $10 \%$ (13.4 \% and $12 \%$, respectively), and $20.5 \%$ was achieved with CFSR, However, CHIRPSv2.0 did not register minimal rain with either PS1 or PS2. Similar values were provided by GP in PS2, although the registered data in this station exceeded $6 \%$. Differences in light rain (between 1 and $2 \mathrm{~mm}$ ) were reduced to around $1 \%$ between the observed data in both stations and GP, except for CHIRPSv2.0, which rarely showed precipitation of this amount $(0.2 \%$ and $0.3 \%$ in PS1 and PS2, respectively). The disparities between PS and PERSIANN-CDR, CFSR and MSWEPv1.1 were doubled with moderate rain (between 2 and $10 \mathrm{~mm}$ ), while CHIRPSv2.0 and CMORPH values remained relatively similar to observed data. CMORPH and CFSR reached similar values to PS (16\% and 13\% for PS1 and PS2, respectively) for heavy rain (between 10 and $50 \mathrm{~mm}$ ), while the remaining GPs increased observed values at approximately $50 \%$. Violent rain (above $50 \mathrm{~mm}$ ) was underestimated for all GPs studied, except in the case of MORPH, which halved observed percentages in PS1 and PS2 (18\% and 12\%, respectively) or even without detecting them, as in the case of PERSIANN-CDR. On the assumption that the observed data in PS1 and PS2 are accurate, GP tended to underestimate extreme events on dry days except for CHIRPSv2.0 and in extremely high rainfall except for MORPH. These percentage differences also resulted in disparities in the remaining event ranges considered. However, GP performance varied substantially depending both on the segment of the amount of rain and the dataset considered. CMORPH appeared to be the best fit GP for precipitation above $1 \mathrm{~mm}$. PERSIANN-CDR, CHIRPSv2.0 and MSWEPv1.1 overestimated precipitation in moderate and heavy rain events. CFSR did not follow a specific pattern with regard to the precipitation event classification, as shown in Table 3.
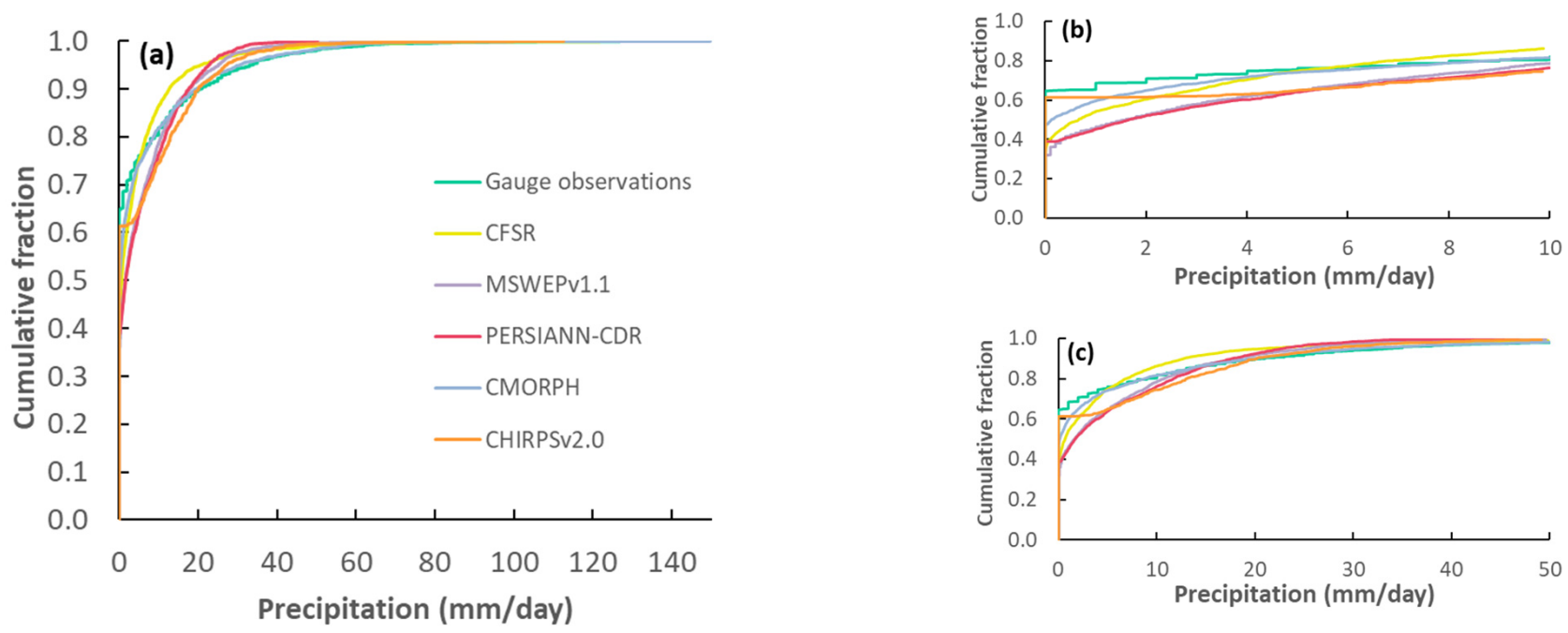

Figure 5. Distribution of daily precipitation values of the six precipitation inputs at PS-1: (a) distribution of all precipitation values; (b) distribution of precipitation $<10 \mathrm{~mm}$; (c) distribution of $10 \mathrm{~mm} \leq$ precipitation $\leq 50 \mathrm{~mm}$. 

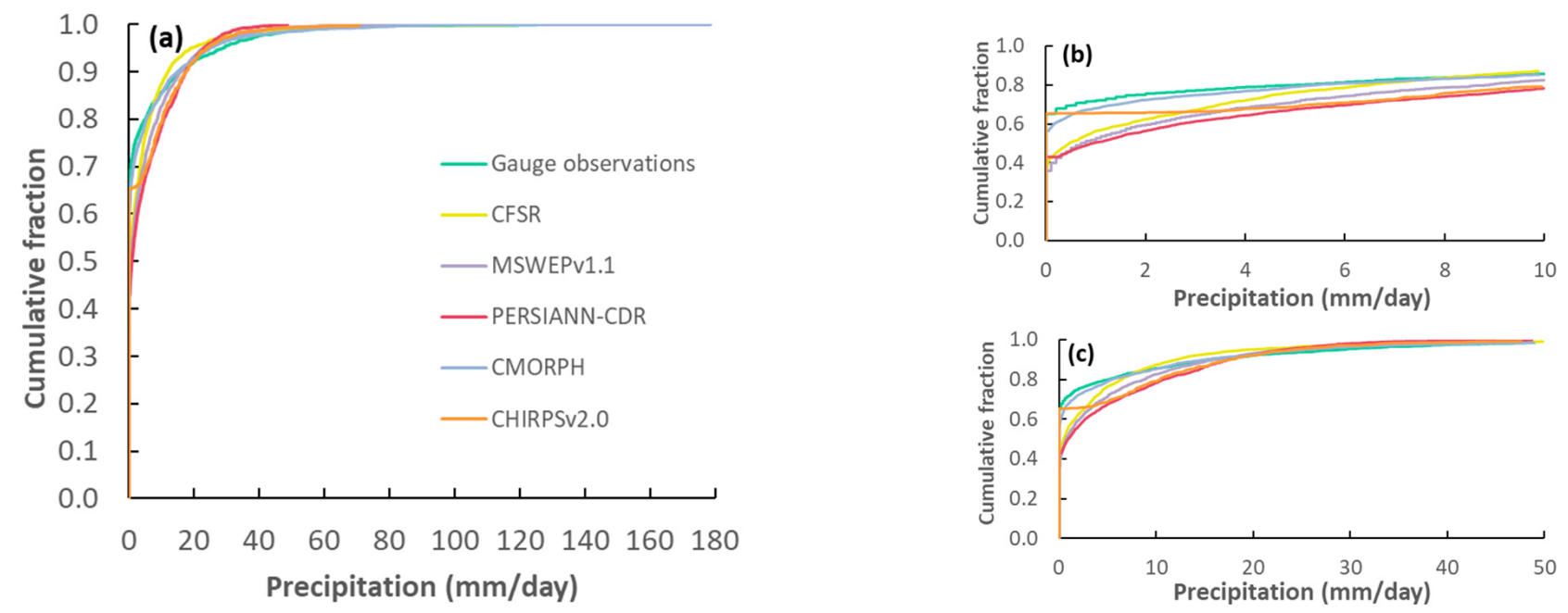

Figure 6. Distribution of daily precipitation values of the six precipitation inputs at PS-2: (a) distribution of all precipitation values; (b) distribution of precipitation $<10 \mathrm{~mm}$; (c) distribution of $10 \mathrm{~mm} \leq$ precipitation $\leq 50 \mathrm{~mm}$.

The annual variability of the different datasets is shown in Figure 7. The results of annual precipitation again show that CMORPH presented the smallest deviation from the observed data, whilst CFSR was the dataset with the lowest precipitation for both precipitation stations. The annual variability between the years 2005 and 2006, 2007 and 2008, and 2009 and 2010 were similar to those observed at station PS-1. At station PS-2, the period 2007-2010 showed the same variability as the observed data. CMORPH showed the same annual variability in all years as the observed data at station PS-1 and PERSIANNCDR and CHIRPSv2.0 at station PS-2. In the case of PS-2, 2009 was the driest year in all cases. In contrast, the wettest year was 2010 for all data and both stations, except for MSWEPv1.1 in the case of PS-2, where it was 2008.
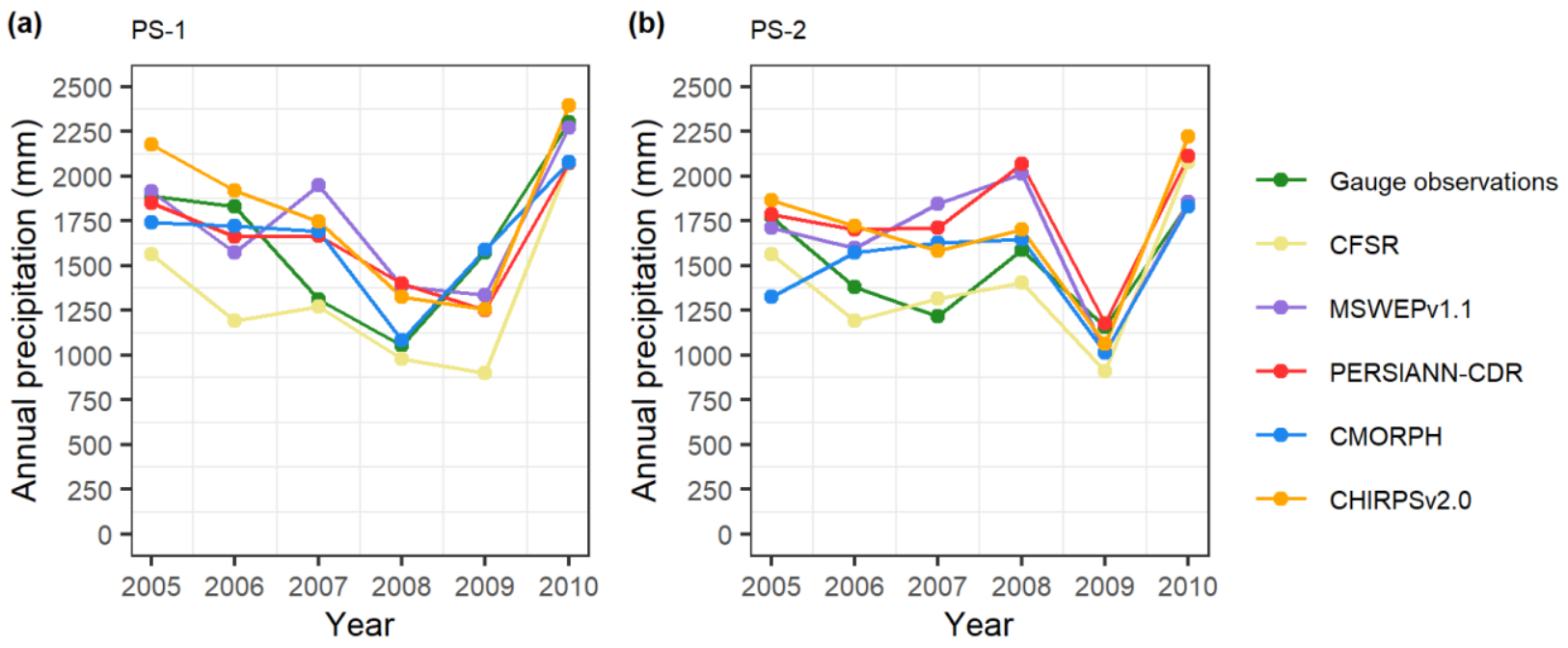

Figure 7. Annual precipitation in: (a) PS-1 station and (b) PS-2 station.

The divergent results of the different global precipitation products demonstrate that no particular GP product performs better in general. In other words, more research is needed in the different hydro-climatic regions to explore and assess their usefulness as an alternative to the observed data in data-scarce regions. Therefore, the different GP products must be validated for each case study, which means that the simulation of streamflow is mandatory in regions with poor data. 


\subsection{Performance of GP Products in Simulating Streamflow}

During the second stage, the performances of the five GP products and the data from the ground gauges were evaluated as an input to the SWAT model to simulate the observed streamflow in the three stream gauges (SG-1, SG-2, and SG-3). In the first approach of this study, the best-fit parameters found for the SWAT model with the precipitation gauge observation data were used to simulate the streamflow with each GP product as an input, and the results are illustrated in Table 9.

Table 9. Performance of SWAT simulations on a monthly scale derived with the best-fitted parameters calibrated with precipitation gauge stations for calibration (2005-2007) and validation (2008-2010) for three gauge stations.

\begin{tabular}{|c|c|c|c|c|c|}
\hline Stream Gauge/Criteria & CFSR & MSWEPv1.1 & PERSIANN-CDR & CMORPH & CHIRPSv2.0 \\
\hline \multicolumn{6}{|c|}{ SG-1 calibration (validation) } \\
\hline $\mathrm{R}^{2}$ & $0.54(0.68)$ & $0.75(0.65)$ & $0.76(0.72)$ & $0.63(0.60)$ & $0.80(0.82)$ \\
\hline NSE & $0.39(0.63)$ & $0.67(0.64)$ & $0.69(0.71)$ & $0.36(0.58)$ & $0.51(0.80)$ \\
\hline PBIAS & $31.97(25.56)$ & $11.92(11.57)$ & $18.71(6.03)$ & $1.70(0.78)$ & $-10.49(-6.30)$ \\
\hline RSR & $0.78(0.61)$ & $0.57(0.60)$ & $0.56(0.54)$ & $0.80(0.65)$ & $0.70(0.45)$ \\
\hline \multicolumn{6}{|c|}{ SG-2 calibration (validation) } \\
\hline $\mathrm{R}^{2}$ & $0.60(0.69)$ & $0.77(0.66)$ & $0.78(0.70)$ & $0.63(0.60)$ & $0.80(0.82)$ \\
\hline NSE & $0.42(0.62)$ & $0.67(0.63)$ & $0.68(0.68)$ & $0.34(0.58)$ & $0.50(0.80)$ \\
\hline PBIAS & $33.99(26.73)$ & $15.49(16.46)$ & $24.43(12.31)$ & $8.24(7.21)$ & $-5.06(-3.20)$ \\
\hline RSR & $0.76(0.62)$ & $0.57(0.61)$ & $0.57(0.56)$ & $0.81(0.65)$ & $0.70(0.45)$ \\
\hline \multicolumn{6}{|c|}{ SG-3 calibration (validation) } \\
\hline $\mathrm{R}^{2}$ & $0.62(0.67)$ & $0.78(0.65)$ & $0.79(0.71)$ & $0.65(0.59)$ & $0.82(0.81)$ \\
\hline NSE & $0.44(0.61)$ & $0.67(0.63)$ & $0.68(0.69)$ & $0.34(0.57)$ & $0.53(0.79)$ \\
\hline PBIAS & $34.19(25.79)$ & $16.08(16.58)$ & $25.56(12.63)$ & $9.53(7.46)$ & $-3.47(-3.24)$ \\
\hline RSR & $0.75(0.63)$ & $0.57(0.61)$ & $0.57(0.56)$ & $0.82(0.66)$ & $0.69(0.46)$ \\
\hline
\end{tabular}

No relevant disparities in water balance were found between GPs and the baseline model using the best-adjusted parameters for gauge observations input. The mean ratio of annually observed streamflow to annual precipitation was 0.28 to compensate for the GP overestimating precipitation. Most of the total streamflow in all the GP (around $87 \%$ ) came from surface runoff, while aquifer recharge accounted for less than $2.5 \%$ of total precipitation, reproducing the baseline model, with $2 \%$. The mean ratio ET to total precipitation was similar for all the GPs at approximately 0.45 .

In the case of models that use CFSR and CMORPH as the input, the indexes did not deliver good results, despite the good statistics obtained with CMORPH when comparing precipitation data. PBIAS for PERSIIAN-CDR and RSR for CHIRPS worsened considerably in the calibration phase. CFSR presented the worst values of PBIAS against the other GP products. MSWEPv1.1 showed better performance in terms of $R^{2}$, NSE, and RSR in the validation period. Based on the criteria of Moriasi et al. [64], the models simulated with CFSR and CMORPH were unsatisfactory according to the NSE and RSR indexes. However, models driven by MSWEPv1.1, PERSIANN-CDR, and CHIRPSv2.0 were satisfactory except for the PBIAS statistic with PERSIANN-CDR at station SG-3 which reached the limit value of $25 \%$ in the calibration period. In conclusion, in the first approach, PERSIANN-CDR and CHIRPSv2.0 were the precipitation products that performed best in the streamflow simulations during the validation period. Given the large number of parameters involved in model calibration, a second approach was additionally used to evaluate the GP products. In this second approach, the SWAT model was calibrated for each of the precipitation products. The values of the calibrated parameters in each case are shown in Table 10. Most of the parameters show significant differences depending on the dataset used. While CN2 remained almost unchanged for $\mathrm{CMORPH}$, there was a slight decrease in the initial value for gauge stations and CFSR and reductions higher than 10\% for MSWEPv1.1, CHIRPSv2.0 and PERSIAN-CDR. The latter reached 19\%, characterizing the basin as having high permeability. According to the ALPHA_BF values, the response to aquifer recharge is 
very low for gauge stations, CFSR, CMORPH and CHIRPSv2.0, unlike MSWEPv1.1 and PERSIANN-CDR, which is in line with the hydrology of the basin. Similar conclusions can be drawn when analysing RCHRG_DP fitted values. Parameters related to HRUs' slope (SLSUBBSN and HRU_SLP) showed significant differences between datasets, which varied in a wide range $(-0.48-0.42)$. The resistance to flood flows in the main channel measured by $\mathrm{CH} \_\mathrm{N} 2$ contributes (together with its hydraulic conductivity $\left(\mathrm{CH}_{-} \mathrm{K} 2\right)$ ) to water transfer mechanisms and surface runoff. CMORPH and CHIRPSv2.0 provide abnormally low roughness values (0.01). Furthermore, MSWEPv1.1 and PERSIANN-CDR show a moderate loss rate, according to Lane et al. [66] (hydraulic conductivity below $25 \mathrm{~mm} / \mathrm{h}$ ), and CMORPH and CHIRPSv2.0 reach values above $75 \mathrm{~mm} / \mathrm{h}$, which indicate a high loss rate. While this should correspond with clean sand and gravel as a bed material in the channel, it does not reflect the riverbed's reality. Soil parameters were also significantly different depending on the GP. Thus, SOL_AWC increased the initial value in all datasets but CFSR and MSWEPv1.1, and decreased the stream flow due to the ability of soil to retain more water [67].

Table 10. SWAT parameter values calibrated with each of the precipitation sources.

\begin{tabular}{|c|c|c|c|c|c|c|}
\hline \multirow{2}{*}{ Parameter } & \multicolumn{6}{|c|}{ Parameter Values } \\
\hline & Precipitation Gauge Data & CFSR & MSWEPv1.1 & PERSIANN-CDR & CMORPH & CHIRPSv2.0 \\
\hline r_CN2 & -0.06 & -0.07 & -0.14 & -0.19 & -0.02 & -0.11 \\
\hline v_ALPHA_BF & 0.14 & 0.03 & 0.82 & 0.47 & 0.02 & 0.02 \\
\hline v_GWQMN & 3568.33 & 3313 & 4425 & 3737.5 & 4712.5 & 3385 \\
\hline v_GW_REVAP & 0.12 & 0.12 & 0.10 & 0.15 & 0.08 & 0.12 \\
\hline v_RCHRG_DP & 0.09 & 0.15 & 0.54 & 0.44 & 0.02 & 0.01 \\
\hline v_SHALLST & 92.33 & 594.25 & 657 & 521.5 & 937.5 & 1062.5 \\
\hline v_CANMX & 28.38 & 28.55 & 29.05 & 16.57 & 32.58 & 19.55 \\
\hline r_SLSUBBSN & 0.42 & 0.23 & -0.24 & 0.25 & -0.28 & -0.18 \\
\hline r_HRU_SLP & -0.48 & -0.21 & -0.45 & -0.01 & 0.31 & 0.24 \\
\hline v_ESCO & 0.85 & 0.58 & 0.40 & 0.56 & 0.75 & 0.73 \\
\hline v_SURLAG & 12.86 & 7.96 & 15.15 & 7.74 & 9.26 & 5.79 \\
\hline v_CH_N2 & 0.13 & 0.03 & 0.24 & 0.10 & 0.01 & 0.01 \\
\hline v_CH_K2 & 39.65 & 44.24 & 8.65 & 16.15 & 116.93 & 77.95 \\
\hline r_SOL_AWC & 0.07 & -0.08 & -0.02 & 0.02 & 0.16 & 0.07 \\
\hline r_SOL_BD & -0.08 & 0.03 & 0.09 & 0.02 & -0.13 & -0.06 \\
\hline r_SOL_Z & -0.24 & 0.13 & -0.27 & -0.16 & 0.22 & 0.04 \\
\hline
\end{tabular}

Concerning the balance models obtained, the mean ratio of annual observed streamflow to annually precipitation for the studied period (2005-2010) was 0.32 , ranging from 0.21 to 0.40 for PERSIANN-CDR and CMORPH, respectively. In the case of the SWAT model for the precipitation gauge data, this ratio was 0.35 and $91 \%$ of the total flow came from surface run-off. The proportion between surface run-off and base flow was more balanced in PERSIANN-CDR, CHIRPSv2.0 and MSWEPv1.1, where the percentages were around $60 \%$ and $40 \%$, respectively. Consequently, the highest differences in models were found in the recharge to the aquifer, which was almost $0 \%$ in all models except in PERSIANN-CDR and MSWEPv1.1, where the ratio of deep recharge to total precipitation was 0.15 and 0.19 , respectively. The latter is consistent with previous hydrogeological studies in Central American aquifers [52,53], which indicated high permeability and faster response recharge. No discrepancies were found regarding the ratio ET to total precipitation, which varied from 0.42 (gauge station and CHIRPSv2.0) to 0.50 (CFSR), highlighting the relevance of precipitation data in water balance.

Table 11 shows the calibration and validation model results on a monthly scale with each precipitation dataset. In general, SWAT simulations based on the best-fit parameters for each GP product showed a better performance in terms of $\mathrm{R}^{2}$, NSE, PBIAS, and RSR compared to the simulation results using GP products with the best-adjusted parameters for gauge observations input. The performance indices were better in calibration and 
validation, except for the PBIAS index using CHIRPSv2.0. In concrete terms, the NSE values increased slightly in calibration (approximately 0.15 ) and had minimal variation in validation for the model driven by PERSIANN-CDR. On the other hand, in the model driven by CHIRPSv2.0, there was a significant increase in the NSE values of about 0.31 in calibration and a slight increase (about 0.08 ) in validation. Similar results were obtained by Bitew et al. [33], who revealed significant improvements in the simulations when the models were calibrated with each of the precipitation products rather than with observed data. In terms of $\mathrm{R}^{2}$, NSE, and RSR, the SWAT model with PERSIANN-CDR and CHIRPSv2.0 as inputs simulated the streamflow with the best results in both the calibration and validation for the three stream gauges.

Table 11. Performance of SWAT simulations at a monthly scale based on the input of different precipitation products for calibration (2005-2007) and validation (2008-2010) for three stream gauges.

\begin{tabular}{|c|c|c|c|c|c|c|}
\hline $\begin{array}{c}\text { Stream } \\
\text { Gauge/Criteria }\end{array}$ & $\begin{array}{c}\text { Precipitation } \\
\text { Gauge Data }\end{array}$ & CFSR & MSWEPv1.1 & $\begin{array}{l}\text { PERSIANN- } \\
\text { CDR }\end{array}$ & CMORPH & CHIRPSv2.0 \\
\hline \multicolumn{7}{|c|}{ SG-1 calibration (validation) } \\
\hline $\mathrm{R}^{2}$ & $0.73(0.61)$ & $0.68(0.79)$ & $0.76(0.59)$ & $0.83(0.71)$ & $0.58(0.62)$ & $0.82(0.90)$ \\
\hline NSE & $0.70(0.60)$ & $0.62(0.77)$ & $0.71(0.57)$ & $0.82(0.69)$ & $0.56(0.57)$ & $0.79(0.87)$ \\
\hline PBIAS & $-7.48(10.37)$ & $-1.03(-6.41)$ & $-16.63(-15.10)$ & $-4.76(-13.66)$ & $-13.36(-13.58)$ & $-14.52(-12.15)$ \\
\hline RSR & $0.55(0.63)$ & $0.62(0.48)$ & $0.54(0.66)$ & $0.43(0.56)$ & $0.67(0.66)$ & $0.46(0.37)$ \\
\hline \multicolumn{7}{|c|}{ SG-2 calibration (validation) } \\
\hline $\mathrm{R}^{2}$ & $0.77(0.63)$ & $0.74(0.79)$ & $0.78(0.57)$ & $0.85(0.70)$ & $0.60(0.62)$ & $0.84(0.91)$ \\
\hline NSE & $0.76(0.61)$ & $0.67(0.76)$ & $0.72(0.56)$ & $0.84(0.69)$ & $0.60(0.58)$ & $0.83(0.88)$ \\
\hline PBIAS & $1.13(16.85)$ & $0.20(-6.26)$ & $-13.82(-11.52)$ & $1.03(-7.75)$ & $-5.60(-7.37)$ & $-8.50(-12.53)$ \\
\hline RSR & $0.49(0.63)$ & $0.58(0.49)$ & $0.53(0.66)$ & $0.39(0.55)$ & $0.63(0.65)$ & $0.41(0.35)$ \\
\hline \multicolumn{7}{|c|}{ SG-3 calibration (validation) } \\
\hline $\mathrm{R}^{2}$ & $0.77(0.62)$ & $0.76(0.78)$ & $0.78(0.57)$ & $0.85(0.71)$ & $0.62(0.61)$ & $0.85(0.91)$ \\
\hline NSE & $0.76(0.59)$ & $0.67(0.73)$ & $0.72(0.56)$ & $0.84(0.70)$ & $0.62(0.58)$ & $0.84(0.88)$ \\
\hline PBIAS & $3.11(17.34)$ & $-0.10(-8.11)$ & $-13.59(-12.31)$ & $2.14(-7.67)$ & $-3.99(-7.20)$ & $-6.39(-14.24)$ \\
\hline RSR & $0.49(0.64)$ & $0.57(0.52)$ & $0.53(0.67)$ & $0.39(0.54)$ & $0.62(0.65)$ & $0.40(0.34)$ \\
\hline
\end{tabular}

The CFSR-driven simulation obtained the lowest PBIAS values for all three gauges, except for SG-3 in the validation period, where the best results were obtained using the PERSIANN-CDR and CMORPH datasets. The simulated streamflow driven by the MSWEPv1.1 and CMORPH datasets obtained the poorest fits with the observed streamflow. In accordance with NSE, PBIAS, and RSR, SWAT's performances for all precipitation inputs were satisfactory (defined as NSE $>0.5$, PBIAS $< \pm 25$, and RSR $\leq 0.7$ [52]), in both the calibration and validation periods. Very good model performances (defined as NSE > 0.75) were obtained for PERSIANN-CDR and CHIRPSv2.0. Based on the results of the four indexes, it is concluded that the results of the streamflow simulation on a monthly scale driven by the PERSIANN-CDR and CHIRPSv2.0 products were better than those obtained with the observed precipitation data, meaning that the use of PERSIANN-CDR and CHIRPSv2.0 was advantageous for the observed data. Notwithstanding, comparative techniques similar to those undertaken must be carried out to avoid parameter overfitting. Furthermore, water balance analysis revealed that there was not aquifer recharge with CHIRPSv2.0, which is inconsistent with hydrological characteristics of the basin. Thus, PERSIANN-CDR was the most stable and appropriate product to simulate the streamflow in the GSM River Basin. Figure 8 presents a comparison of the streamflow simulations using the best-fit parameters for the precipitation gauge observations data for the calibration (2005-2007) and validation (2008-2009) periods. The streamflow simulation conducted by CFSR, MSWEPv1.1, and PERSIANN-CDR resulted in reduced wet and dry season flows, underestimating the observed streamflow as shown in the PBIAS (Table 9).

Figure 9 shows the comparison of the streamflow simulations for each precipitation dataset input with observed monthly streamflow using model parameters calibrated for each dataset. 
(a) SG-1

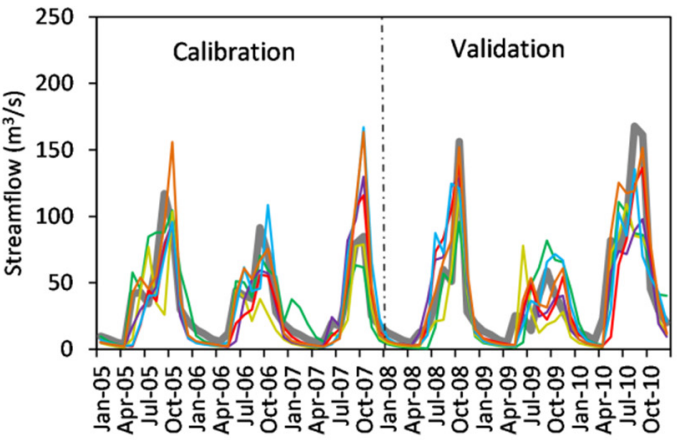

(c) SG-3

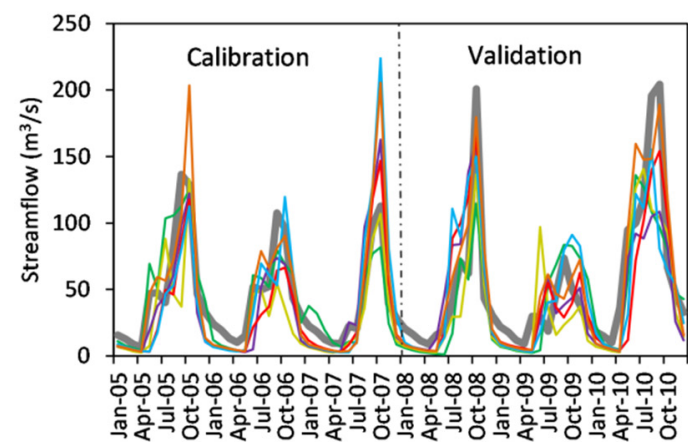

(b) SG-2

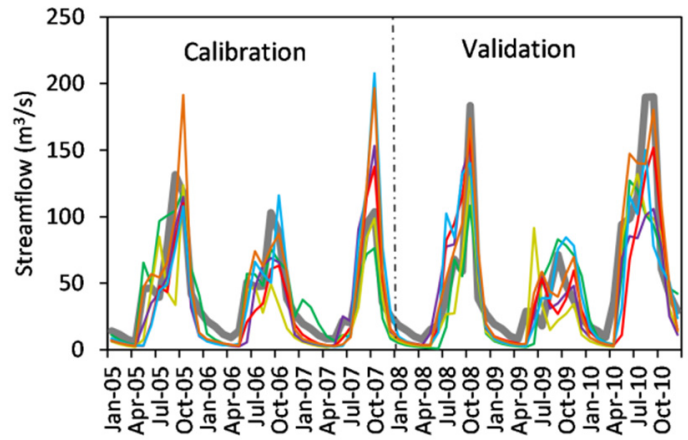

Figure 8. Comparison of simulated streamflow for different precipitation sources and observed monthly streamflow using Table 1. (a) SG-1, (b) SG-2, and (c) SG-3.
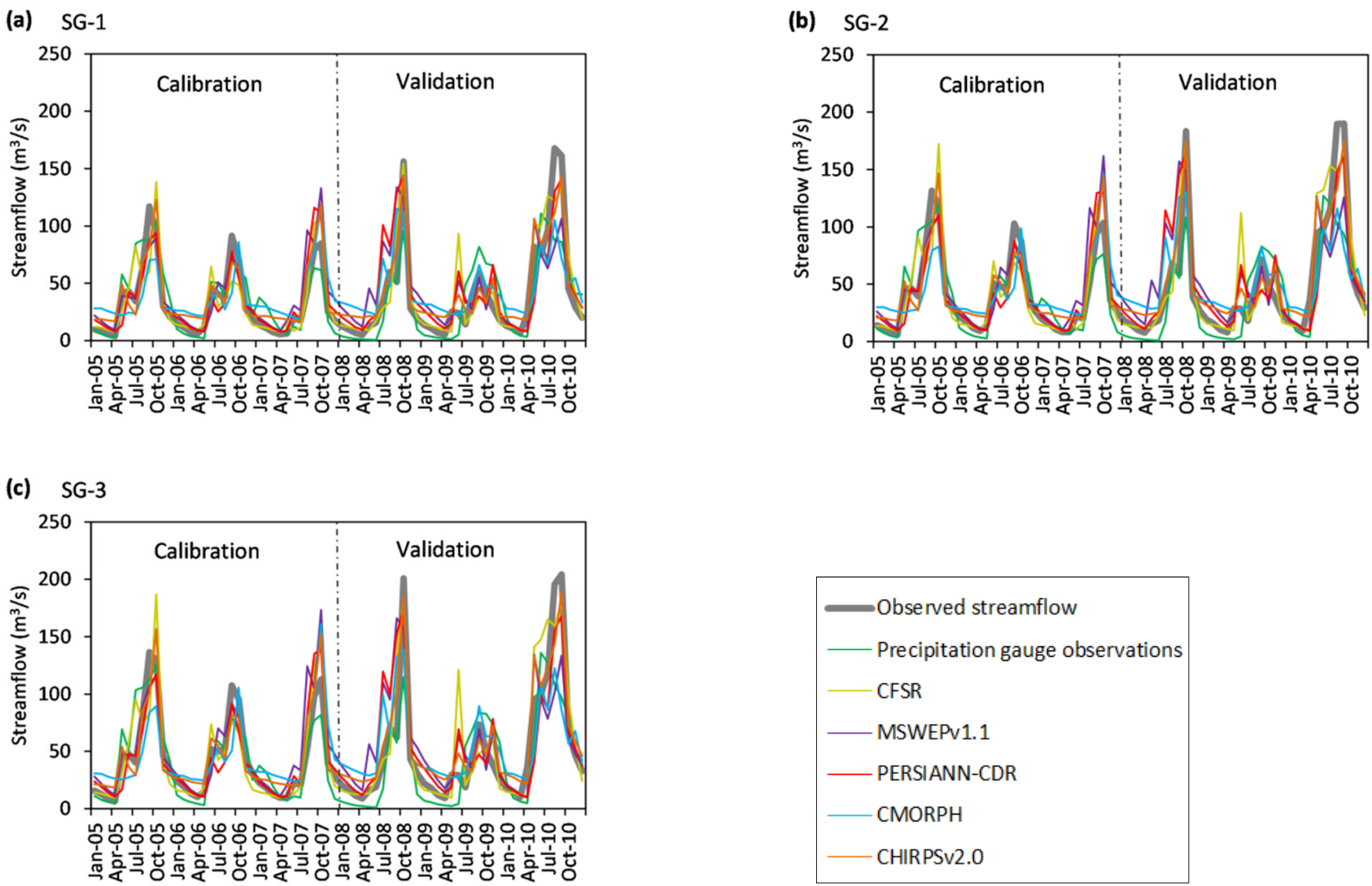

Figure 9. Comparison of simulated streamflow for different precipitation sources and observed monthly streamflow using model parameters calibrated for each dataset in (a) SG-1, (b) SG-2, and (c) SG-3. 
The simulation based on precipitation gauge data input overlooked the highest peak flows in the calibration and validation periods, which suggests that this dataset was not able to capture the precipitation events that produced these peaks. Moreover, the streamflow simulated with the data from the precipitation gauges was lower than the observed streamflow and the GP products. In all the simulations, the observed highest peak flows of the validation period were not reached. The maximum peak flows simulated with GP products are produced by CFSR and CHIRPSv2.0 for all three gauges. Regarding the modelling of low flows for the dry season, CFSR, MSWEPv1.1, and PERSIANN-CDR modelled them well in general. However, CMORPH and CHIRPSv2.0 overestimated these flows. The streamflow simulated with the CMORPH and CHIRPSv2.0 products indicated an increase in peak flows and a decrease in low flows compared with the first approach, decreasing the differences with respect to the observed flows, as reflected in a decline in PBIAS (Tables 9 and 11).

The advantage of using gridded versus the point data shown in the present study may be due to the following [3]: (1) observed historical data were scarce and poor in the basin; (2) these data may also be subject to error due to malfunctioning of installed equipment; and (3) there are often significant differences between point scale meter information and actual rainfall in an area. It is therefore advisable to use gridded datasets rather than a few point scale meters.

\section{Conclusions}

The spatial and temporal accuracy of precipitation data is crucial for the reliable simulation of hydrological processes. Streamflow simulation in El Salvador basins is a challenging task due to very sparse and unreliable ground-based precipitation information. This study assessed the capacity of five high-resolution GP products to provide reliable precipitation information for the application of streamflow simulation in this region.

After a comprehensive analysis, the following conclusions were drawn: (1) concerning the comparison of precipitation sources, the divergent results demonstrate that no particular GP product performs better in general; (2) in terms of the ability of the different datasets to simulate streamflow, the simulations using the selected GP products provided realistic and acceptable models; (3) the results of the simulation of the streamflow driven by PERSIANNCDR and CHIRPSv2.0 products fitted better than those obtained from the data of the precipitation gauges; (4) PERSIANN-CDR was the most adequate and stable dataset to simulate the streamflow in the GSM River Basin; (5) the type of GP dataset significantly influences model performance; (6) GP products have potential use for hydrology purposes; (7) the performance of the models improves when they are calibrated with the specific precipitation instead of a rain gauge input.

Despite the satisfactory results for most of the precipitation products evaluated in this studied area, it is recommended to evaluate the datasets before using them for hydrological studies in other specific sites. In future research, other and newer GP products can be analyzed to determine whether the results can be improved. Moreover, lower timescales of both precipitation and streamflow could be assessed.

The contribution of this study was particularly relevant, since it was the first assessment of the accuracy of GP datasets in the hydrological modelling of a poorly gauged basin in El Salvador in Central America Water management, and climate change studies could be more accurately conducted in data-poor regions with calibrated and validated GP. This research can be performed in areas or countries with a similar problem relating to the non-availability of data.

Supplementary Materials: The following are available online at https:/ /www.mdpi.com/article/10 $.3390 / w 13182497 / \mathrm{s} 1$.

Author Contributions: Conceptualization, P.J.-S., J.S.-A. and P.B.-G.; Formal analysis, P.J.-S., J.S.-A. and P.B.-G.; Funding acquisition, J.M.C.; Investigation, J.S.-A.; Methodology, P.J.-S. and P.B.-G.; 
Software, P.J.-S.; Supervision, J.P.-S. and J.M.C.; Validation, J.P.-S.; Writing—review and editing, P.J.-S., J.P.-S., J.S.-A. and P.B.-G. All authors have read and agreed to the published version of the manuscript.

Funding: This research was funded by Ministerio de Ciencia e Innovación of España (grant numbers RTI2018-096384-B-I00, RTC-2017-6389-5 and RTC2019-007159-5) and by Ramon y Cajal Program (grant number RYC2018-025580-I).

Institutional Review Board Statement: Not applicable.

Informed Consent Statement: Not applicable.

Data Availability Statement: Not applicable.

Acknowledgments: The authors are grateful to Ministerio de Medio Ambiente y Recursos Naturales (MARN) of El Salvador for providing the data necessary for this study, and also to Scribbr editing services for proofreading the text.

Conflicts of Interest: The authors declare no conflict of interest.

\section{References}

1. Duan, Z.; Tuo, Y.; Liu, J.; Gao, H.; Song, X.; Zhang, Z.; Yang, L.; Mekonnen, D.F. Hydrological Evaluation of Open-Access Precipitation and Air Temperature Datasets Using SWAT in a Poorly Gauged Basin in Ethiopia. J. Hydrol. 2019, 569, $612-626$. [CrossRef]

2. Woldemeskel, F.M.; Sivakumar, B.; Sharma, A. Merging Gauge and Satellite Rainfall with Specification of Associated Uncertainty across Australia. J. Hydrol. 2013, 499, 167-176. [CrossRef]

3. Senent-Aparicio, J.; López-Ballesteros, A.; Pérez-Sánchez, J.; Segura-Méndez, F.; Pulido-Velazquez, D. Using Multiple Monthly Water Balance Models to Evaluate Gridded Precipitation Products over Peninsular Spain. Remote Sens. 2018, 10, 922. [CrossRef]

4. Jimeno-Sáez, P.; Pulido-Velazquez, D.; Collados-Lara, A.-J.; Pardo-Igúzquiza, E.; Senent-Aparicio, J.; Baena-Ruiz, L. A Preliminary Assessment of the "Undercatching" and the Precipitation Pattern in an Alpine Basin. Water 2020, 12, 1061. [CrossRef]

5. Sevruk, B. Adjustment of Tipping-Bucket Precipitation Gauge Measurements. Atmos. Res. 1996, 42, 237-246. [CrossRef]

6. Soo, E.Z.X.; Jaafar, W.Z.W.; Lai, S.H.; Islam, T.; Srivastava, P. Evaluation of Satellite Precipitation Products for Extreme Flood Events: Case Study in Peninsular Malaysia. J. Water Clim. Chang. 2019, 10, 871-892. [CrossRef]

7. Beck, H.E.; van Dijk, A.I.J.M.; Levizzani, V.; Schellekens, J.; Miralles, D.G.; Martens, B.; de Roo, A. MSWEP: 3-Hourly 0.25 $5^{\circ}$ Global Gridded Precipitation (1979-2015) by Merging Gauge, Satellite, and Reanalysis Data. Hydrol. Earth Syst. Sci. 2017, $21,589-615$. [CrossRef]

8. Ashouri, H.; Hsu, K.-L.; Sorooshian, S.; Braithwaite, D.K.; Knapp, K.R.; Cecil, L.D.; Nelson, B.R.; Prat, O.P. PERSIANN-CDR: Daily Precipitation Climate Data Record from Multisatellite Observations for Hydrological and Climate Studies. Bull. Amer. Meteorol. Soc. 2015, 96, 69-83. [CrossRef]

9. Joyce, R.J.; Janowiak, J.E.; Arkin, P.A.; Xie, P. CMORPH: A Method That Produces Global Precipitation Estimates from Passive Microwave and Infrared Data at High Spatial and Temporal Resolution. J. Hydrometeorol. 2004, 5, 17. [CrossRef]

10. Funk, C.; Peterson, P.; Landsfeld, M.; Pedreros, D.; Verdin, J.; Shukla, S.; Husak, G.; Rowland, J.; Harrison, L.; Hoell, A.; et al. The Climate Hazards Infrared Precipitation with Stations-A New Environmental Record for Monitoring Extremes. Sci. Data 2015, 2, 150066. [CrossRef] [PubMed]

11. Saha, S.; Moorthi, S.; Wu, X.; Wang, J.; Nadiga, S.; Tripp, P.; Behringer, D.; Hou, Y.-T.; Chuang, H.; Iredell, M.; et al. The NCEP Climate Forecast System Version 2. J. Clim. 2014, 27, 2185-2208. [CrossRef]

12. Bitew, M.M.; Gebremichael, M. Assessment of Satellite Rainfall Products for Streamflow Simulation in Medium Watersheds of the Ethiopian Highlands. Hydrol. Earth Syst. Sci. 2011, 15, 1147-1155. [CrossRef]

13. Baez-Villanueva, O.M.; Zambrano-Bigiarini, M.; Ribbe, L.; Nauditt, A.; Giraldo-Osorio, J.D.; Thinh, N.X. Temporal and Spatial Evaluation of Satellite Rainfall Estimates over Different Regions in Latin-America. Atmos. Res. 2018, 213, 34-50. [CrossRef]

14. Dinku, T.; Ruiz, F.; Connor, S.J.; Ceccato, P. Validation and Intercomparison of Satellite Rainfall Estimates over Colombia. J. Appl. Meteorol. Climatol. 2010, 49, 1004-1014. [CrossRef]

15. Elgamal, A.; Reggiani, P.; Jonoski, A. Impact Analysis of Satellite Rainfall Products on Flow Simulations in the Magdalena River Basin, Colombia. J. Hydrol. Reg. Stud. 2017, 9, 85-103. [CrossRef]

16. Hirpa, F.A.; Gebremichael, M.; Hopson, T. Evaluation of High-Resolution Satellite Precipitation Products over Very Complex Terrain in Ethiopia. J. Appl. Meteorol. Climatol. 2010, 49, 1044-1051. [CrossRef]

17. Le, M.-H.; Lakshmi, V.; Bolten, J.; Bui, D.D. Adequacy of Satellite-Derived Precipitation Estimate for Hydrological Modeling in Vietnam Basins. J. Hydrol. 2020, 586, 124820. [CrossRef]

18. Arnold, J.G.; Srinivasan, R.; Muttiah, R.S.; Williams, J.R. Large Area Hydrologic Modeling and Assessment Part I: Model Development. J. Am. Water Resour. Assoc. 1998, 34, 73-89. [CrossRef]

19. Liu, R.; Xu, F.; Zhang, P.; Yu, W.; Men, C. Identifying Non-Point Source Critical Source Areas Based on Multi-Factors at a Basin Scale with SWAT. J. Hydrol. 2016, 533, 379-388. [CrossRef] 
20. Liu, Y.; Wang, R.; Guo, T.; Engel, B.A.; Flanagan, D.C.; Lee, J.G.; Li, S.; Pijanowski, B.C.; Collingsworth, P.D.; Wallace, C.W. Evaluating Efficiencies and Cost-Effectiveness of Best Management Practices in Improving Agricultural Water Quality Using Integrated SWAT and Cost Evaluation Tool. J. Hydrol. 2019, 577, 123965. [CrossRef]

21. López-Ballesteros, A.; Senent-Aparicio, J.; Martínez, C.; Pérez-Sánchez, J. Assessment of Future Hydrologic Alteration Due to Climate Change in the Aracthos River Basin (NW Greece). Sci. Total Environ. 2020, 733, 139299. [CrossRef]

22. Pérez-Sánchez, J.; Senent-Aparicio, J.; Martínez Santa-María, C.; López-Ballesteros, A. Assessment of Ecological and HydroGeomorphological Alterations under Climate Change Using SWAT and IAHRIS in the Eo River in Northern Spain. Water 2020, 12, 1745. [CrossRef]

23. Senent-Aparicio, J.; Alcalá, F.J.; Liu, S.; Jimeno-Sáez, P. Coupling SWAT Model and CMB Method for Modeling of HighPermeability Bedrock Basins Receiving Interbasin Groundwater Flow. Water 2020, 12, 657. [CrossRef]

24. Worku, T.; Khare, D.; Tripathi, S.K. Modeling Runoff-Sediment Response to Land Use/Land Cover Changes Using Integrated GIS and SWAT Model in the Beressa Watershed. Environ. Earth Sci. 2017, 76, 550. [CrossRef]

25. Muche, M.E.; Sinnathamby, S.; Parmar, R.; Knightes, C.D.; Johnston, J.M.; Wolfe, K.; Purucker, S.T.; Cyterski, M.J.; Smith, D. Comparison and Evaluation of Gridded Precipitation Datasets in a Kansas Agricultural Watershed Using SWAT. J. Am. Water Resour. Assoc. 2020, 56, 486-506. [CrossRef]

26. Tolera, M.; Chung, I.-M.; Chang, S. Evaluation of the Climate Forecast System Reanalysis Weather Data for Watershed Modeling in Upper Awash Basin, Ethiopia. Water 2018, 10, 725. [CrossRef]

27. Blanco-Gómez, P.; Jimeno-Sáez, P.; Senent-Aparicio, J.; Pérez-Sánchez, J. Impact of Climate Change on Water Balance Components and Droughts in the Guajoyo River Basin (El Salvador). Water 2019, 11, 2360. [CrossRef]

28. Gao, J.; Sheshukov, A.Y.; Yen, H.; White, M.J. Impacts of Alternative Climate Information on Hydrologic Processes with SWAT: A Comparison of NCDC, PRISM and NEXRAD Datasets. Catena 2017, 156, 353-364. [CrossRef]

29. Wang, N.; Liu, W.; Sun, F.; Yao, Z.; Wang, H.; Liu, W. Evaluating Satellite-Based and Reanalysis Precipitation Datasets with Gauge-Observed Data and Hydrological Modeling in the Xihe River Basin, China. Atmos. Res. 2020, 234, 104746. [CrossRef]

30. Dhanesh, Y.; Bindhu, V.M.; Senent-Aparicio, J.; Brighenti, T.M.; Ayana, E.; Smitha, P.S.; Fei, C.; Srinivasan, R. A Comparative Evaluation of the Performance of CHIRPS and CFSR Data for Different Climate Zones Using the SWAT Model. Remote Sens. 2020, 12, 3088. [CrossRef]

31. Mararakanye, N.; Le Roux, J.J.; Franke, A.C. Using Satellite-Based Weather Data as Input to SWAT in a Data Poor Catchment. Phys. Chem. Earth 2020, 117, 102871. [CrossRef]

32. Radcliffe, D.E.; Mukundan, R. PRISM vs. CFSR Precipitation Data Effects on Calibration and Validation of SWAT Models. J. Am. Water Resour. Assoc. 2017, 53, 89-100. [CrossRef]

33. Bitew, M.M.; Gebremichael, M.; Ghebremichael, L.T.; Bayissa, Y.A. Evaluation of High-Resolution Satellite Rainfall Products through Streamflow Simulation in a Hydrological Modeling of a Small Mountainous Watershed in Ethiopia. J. Hydrometeorol. 2012, 13, 338-350. [CrossRef]

34. Zhu, H.; Li, Y.; Huang, Y.; Li, Y.; Hou, C.; Shi, X. Evaluation and Hydrological Application of Satellite-Based Precipitation Datasets in Driving Hydrological Models over the Huifa River Basin in Northeast China. Atmos. Res. 2018, 207, 28-41. [CrossRef]

35. Blacutt, L.A.; Herdies, D.L.; de Gonçalves, L.G.G.; Vila, D.A.; Andrade, M. Precipitation Comparison for the CFSR, MERRA, TRMM3B42 and Combined Scheme Datasets in Bolivia. Atmos. Res. 2015, 163, 117-131. [CrossRef]

36. Rienecker, M.M.; Suarez, M.J.; Gelaro, R.; Todling, R.; Bacmeister, J.; Liu, E.; Bosilovich, M.G.; Schubert, S.D.; Takacs, L.; Kim, G.-K.; et al. MERRA: NASA's Modern-Era Retrospective Analysis for Research and Applications. J. Clim. 2011, 24, 36243648. [CrossRef]

37. Huffman, G.J.; Bolvin, D.T.; Nelkin, E.J.; Wolff, D.B.; Adler, R.F.; Gu, G.; Hong, Y.; Bowman, K.P.; Stocker, E.F. The TRMM Multisatellite Precipitation Analysis (TMPA): Quasi-Global, Multiyear, Combined-Sensor Precipitation Estimates at Fine Scales. J. Hydrometeorol. 2007, 8, 38-55. [CrossRef]

38. Melo, D.d.C.D.; Xavier, A.C.; Bianchi, T.; Oliveira, P.T.S.; Scanlon, B.R.; Lucas, M.C.; Wendland, E. Performance Evaluation of Rainfall Estimates by TRMM Multi-satellite Precipitation Analysis 3B42V6 and V7 over Brazil. J. Geophys. Res. Atmos. 2015, 120, 9426-9436. [CrossRef]

39. Zambrano-Bigiarini, M.; Nauditt, A.; Birkel, C.; Verbist, K.; Ribbe, L. Temporal and Spatial Evaluation of Satellite-Based Rainfall Estimates across the Complex Topographical and Climatic Gradients of Chile. Hydrol. Earth Syst. Sci. 2017, 21, 1295-1320. [CrossRef]

40. Oliveira, P.T.S.; Nearing, M.A.; Moran, M.S.; Goodrich, D.C.; Wendland, E.; Gupta, H.V. Trends in Water Balance Components across the Brazilian Cerrado. Water Resour. Res. 2014, 50, 7100-7114. [CrossRef]

41. Tan, M.L.; Gassman, P.W.; Liang, J.; Haywood, J.M. A Review of Alternative Climate Products for SWAT Modelling: Sources, Assessment and Future Directions. Sci. Total Environ. 2021, 795, 148915. [CrossRef] [PubMed]

42. Dinh, K.D.; Anh, T.N.; Nguyen, N.Y.; Bui, D.D.; Srinivasan, R. Evaluation of grid-based rainfall products and water balances over the Mekong River basin. Remote Sens. 2020, 12, 1858. [CrossRef]

43. Tang, X.; Zhang, J.; Gao, C.; Ruben, G.B.; Wang, G. Assessing the uncertainties of four precipitation products for swatmodeling in Mekong River basin. Remote Sens. 2019, 11, 304. [CrossRef]

44. Dutta, P.; Sarma, A.K. Hydrological modeling as a tool for water resources management of the data-scarce Brahmaputra basin. J. Water Clim. Change 2020, 12, 152-165. [CrossRef] 
45. Dile, Y.T.; Srinivasan, R. Evaluation of CFSR climate data for hydrologic prediction in data-scarce watersheds: An application in the Blue Nile River Basin. JAWRA J. Am. Water Resour. Assoc. 2014, 50, 1226-1241. [CrossRef]

46. Musie, M.; Sen, S.; Srivastava, P. Comparison and evaluation of gridded precipitation datasets for streamflow simulation in data scarce watersheds of Ethiopia. J. Hydrol. 2019, 579, 124168. [CrossRef]

47. MARN. Plan Nacional de Gestión Integrada del Recurso Hídrico de El Salvador, Con Énfasis en Zonas Prioritarias. Ministerio de Medio Ambiente y Recursos Naturales. Available online: http:/ /rcc.marn.gob.sv/xmlui/handle/123456789/52 (accessed on 1 March 2021).

48. Wozab, D.; Jovel, J.R. Hydrological Analysis of Volcanic Terrane: Lower Basin of the Rio Grande de San Miguel, El Salvador. Hydrol. Sci. J. 1970, 15, 47-66. [CrossRef]

49. Levard, C.; Basile-Doelsch, I. Geology and Mineralogy of Imogolite-Type Materials. In Developments in Clay Science; Elsevier: Amsterdam, The Netherlands, 2016; Volume 7, pp. 49-65. ISBN 978-0-08-100293-3.

50. FAO. Base Referencial Mundial Del Recurso Suelo: Un Marco Conceptual Para Clasificación, Correlación y Comunicación Internacional. Roma, Italy. 2008. Available online: http:/ / www.fao.org/3/a0510s/a0510s.pdf (accessed on 15 June 2021).

51. Sánchez-Murillo, R.; Esquivel-Hernández, G.; Corrales-Salazar, J.L.; Castro-Chacón, L.; Durán-Quesada, A.M.; GuerreroHernández, M.; Delgado, V.; Barberena, J.; Montenegro-Rayo, K.; Calderón, H.; et al. Tracer Hydrology of the Data-scarce and Heterogeneous Central American Isthmus. Hydrol. Process. 2020, 34, 2660-2675. [CrossRef]

52. Jang, W.S.; Engel, B.; Ryu, J. Efficient Flow Calibration Method for Accurate Estimation of Baseflow Using a Watershed Scale Hydrological Model (SWAT). Ecol. Eng. 2018, 125, 50-67. [CrossRef]

53. Sierra Alcocer, R.; Zenteno-Jimenez, E.D.; Barrios, J. Automatic Land Use and Land Cover Classification Using RapidEye Imagery in Mexico. In Proceedings of the AAAI Workshops Workshops at the Twenty-Ninth AAAI Conference on Artificial Intelligence, Austin, TX, USA, 25-26 January 2015. [CrossRef]

54. Tan, M.L.; Yang, X. Effect of Rainfall Station Density, Distribution and Missing Values on SWAT Outputs in Tropical Region. J. Hydrol. 2020, 584, 124660. [CrossRef]

55. World Meteorological Organization. Chapter 14; Observation of present and past weather; state of the ground. In Guide to Meteorological Instruments and Methods of Observation; WMO: Geneva, Switzerland, 2012; pp. I.14-I.19. Available online: http:/ / www.posmet.ufv.br/wp-content/uploads/2016/09/MET-474-WMO-Guide.pdf (accessed on 12 August 2021).

56. Dile, Y.T.; Daggupati, P.; George, C.; Srinivasan, R.; Arnold, J. Introducing a New Open Source GIS User Interface for the SWAT Model. Environ. Modell. Softw. 2016, 85, 129-138. [CrossRef]

57. Tuo, Y.; Duan, Z.; Disse, M.; Chiogna, G. Evaluation of Precipitation Input for SWAT Modeling in Alpine Catchment: A Case Study in the Adige River Basin (Italy). Sci. Total Environ. 2016, 573, 66-82. [CrossRef]

58. Hargreaves, G.H. Defining and Using Reference Evapotranspiration. J. Irrig. Drain. Eng. 1994, 120, 1132-1139. [CrossRef]

59. USDA. National Engineering Handbook, Section 4: Hydrology; US Soil Conservation Service: Washington, DC, USA, 1972.

60. Abbaspour, K.C.; Johnson, C.A.; van Genuchten, M.T. Estimating Uncertain Flow and Transport Parameters Using a Sequential Uncertainty Fitting Procedure. Vadose Zone J. 2004, 3, 1340-1352. [CrossRef]

61. Abbaspour, K.C. SWAT Calibration and Uncertainty Program-A User Manual. SWAT-CUP-2012, 2012th ed.; Swiss Federal Institute of Aquatic Science and Technology: Dubendorf, Switzerland, 2012.

62. Arnold, J.G.; Moriasi, D.N.; Gassman, P.W.; Abbaspour, K.C.; White, M.J.; Srinivasan, R.; Santhi, C.; Harmel, R.D.; van Griensven, A.; Van Liew, M.W.; et al. SWAT: Model Use, Calibration, and Validation. Trans. ASABE 2012, 55, 1491-1508. [CrossRef]

63. Nash, J.E.; Sutcliffe, J.V. River Flow Forecasting through Conceptual Models Part I-A Discussion of Principles. J. Hydrol. 1970, 10, 282-290. [CrossRef]

64. Moriasi, D.N.; Arnold, J.G.; Liew, M.W.V.; Bingner, R.L.; Harmel, R.D.; Veith, T.L. Model Evaluation Guidelines for Systematic Quantification of Accuracy in Watershed Simulations. Trans. ASABE 2007, 50, 885-900. [CrossRef]

65. Magaña, V.; Amador, J.A.; Medina, S. The Midsummer Drought over Mexico and Central America. J. Clim. 1999, 12, 1577-1588. [CrossRef]

66. Lane, L.J.; Ferreira, V.A.; Shirley, E.D. Estimating transmission losses in ephemeral stream channels. In Hydrology and Water Resources in Arizona and the Southwest; Arizona-Nevada Academy of Science: Las Vegas, NV, USA, 1980.

67. Opere, A.O.; Okello, B.N. Hydrologic analysis for river Nyando using SWAT. Hydrol. Earth Syst. Sci. Discuss. 2011, 8, 1765-1797. [CrossRef] 